\title{
New Advances in Biostratigraphy of the Lower/Middle Norian Transition: Conodonts of the Dovško Section, Slovenia
}

\author{
Viktor Karádi ${ }^{*} *^{1}$, Tea Kolar-Jurkovšek ${ }^{2}$, Luka Gale ${ }^{2,3}$, Bogdan Jurkovšek ${ }^{4}$ \\ 1. Department of Palaeontology, Eötvös Loránd University, Budapest 1117, Hungary \\ 2. Geological Survey of Slovenia, Ljubljana 1000, Slovenia \\ 3. Department of Geology, University of Ljubljana, Ljubljana 1000, Slovenia \\ 4. Kamnica 27, 1262 Dol pri Ljubljani, Slovenia \\ (iDViktor Karádi: https://orcid.org/0000-0002-5923-2944
}

\begin{abstract}
This study presents the results of the conodont biostratigraphy and microfacies analysis carried out on the pelagic limestones of the Upper Triassic Dovško Section in Slovenia, which represents the eastern part of the Slovenian Basin. The age of the section ranges from the Lacian 1 to the Alaunian 1. The Lacian part of the succession is predominantly characterized by the representatives of the genus Ancyrogondolella. Transitional morphologies towards Alaunian faunas first appear in the Lacian 3 and become common during the Lacian-Alaunian transition. This evolutionary development coincides with a shift in microfacies from a dominantly radiolarian-bearing mudstone-wackestone-packstone to a filament-dominated wackestone-packstone, and the formation of small neptunian dykes, which may reflect environmental perturbations and/or a change in basin geometry. The proliferation of the genera Epigondolella and Mockina is observed in the Alaunian part of the section, though the genus Ancyrogondolella is still present in this interval. Systematic description of the conodont taxa is provided, and seven new species and two new subspecies are established. The new advances will be of great value in further biostratigraphic studies, especially in areas without ammonoid faunas, and in the reconstruction of the paleogeography of the Slovenian Basin.
\end{abstract}

KEY WORDS: conodonts, microfacies, Late Triassic, Norian, Lacian, Alaunian, Slovenian Basin, cherty limestone.

\section{INTRODUCTION}

The Norian is the longest age of the Triassic, however the fine subdivision of this ca. 20 Ma long time-span is not yet solved. Especially important is the Lacian-Alaunian (lowermiddle Norian) transition, which is characterized by evident turnovers in several marine fossil groups, such as corals (Roniewicz, 2011), ammonoids (Krystyn, 2003) and conodonts (Karádi, 2018; Orchard, 2018). These faunal turnovers seem to coincide with changes in sedimentation in the Tethyan Realm, resulting in the formation of sedimentary breccias and slump structures in the early Alaunian and stratigraphic gaps in condensed Alaunian successions (Karádi, 2018). It is not yet clear whether any connection exists between the turnovers and the sedimentary disturbances, although the lack of an accurate biostratigraphy does not allow the precise timing of these events. Since ammonoids are quite rare in many Alaunian sections, conodonts could be ideal tools for dating this time interval. Understanding the evolutionary

\footnotetext{
*Corresponding author: kavik.geo@gmail.com; karadi.viktor@ttk.elte.hu
}

(C) The Authors 2021. This article is published with open access at Springerlink.com

Manuscript received October 9, 2020.

Manuscript accepted November 27, 2020. changes and faunal diversity throughout the Lacian-Alaunian transition is, however, hampered by a couple of biases. For example, the usage of an oversimplified taxonomy turned Ancyrogondolella rigoi into a wastebasket taxon making the exact range of the species ambiguous and obstructing the recognition of other taxa of possibly great stratigraphic value. A further problem is the high rate of juvenile mortality, which strongly affected conodont animals during the Alaunian and caused the dominance of underdeveloped specimens in many Tethyan assemblages (Karádi et al., 2020; Karádi, 2018). The juvenile and subadult specimens are mostly undeterminable on the species level, which commonly leads to stratigraphic misinterpretations. Investigation of successions rich in adult specimens is thus crucial in order to reveal morphological variability of Norian conodonts, which can serve as a strong base for future phylogenetic and biostratigraphic studies.

The section along the Dovški Potok Stream in East Slovenia fits this criterion. Preliminary studies revealed that fully grown specimens are abundant throughout the succession, in which the Lacian-Alaunian transition is exposed (Karádi et al., 2020, 2019), though the section has not been the subject of detailed stratigraphic research before. The aim of this study is to present the newest results of the conodont biostratigraphy and microfacies analysis of the Dovško succession and contribute to the knowledge on the faunal turnover of the Lacian-Alaunian transition and 
the taxonomy of lower and middle Norian conodonts.

\section{GEOLOGICAL AND PALEOGEOGRAPHICAL SET- TING}

The studied succession is located in the Sava folds region in East Slovenia along the Dovški Potok Stream at Dovško, near Senovo (Fig. 1). In the geological-structural sense, the Sava folds represent a succession of anticlines and synclines extending in the E-W direction, approximately from Celje to the north to Senovo to the south (Poljak, 2007). The folds were formed after the Miocene from a deformed margin of the Adriatic tectonic microplate (Vrabec and Fodor, 2006; Placer, 1999a). The folded succession generally consists of Upper Paleozoic (in a minor extent Lower Triassic) rocks, overthrusted by Permian to Cretaceous formations, which are unconformably overlain by Tertiary sedimentary rocks (Placer, 1999b). According to Buser (1989), Buser et al. (2008) and Rožič (2016), the studied Upper Triassic succession paleogeographically belongs to the eastern part of the Slovenian Basin, a somewhat deeper intraplatform basin that was located at the eastern margin of tropical Pangea during the Triassic. The base of the Slovenian Basin was probably formed early in the Ladinian (Buser et al., 2008; Buser, 1989). The extent of the basin during the Late Triassic is determined from the present-day extent of cherty carbonates. Sections of Norian-Rhaetian dolomite with chert nodules (the "Bača Dolomite") and of the equivalent non-dolomitized limestone of the Slatnik Formation have been researched in western Slovenia (Rožič et al., 2013, 2009; Gale et al., 2012; Gale, 2010; Kolar-Jurkovšek, 1982; Cousin, 1981). However, only little research has been done so far on equivalent beds in eastern Slovenia (Kolar-Jurkovšek and Jurkovšek, 2019; Ogorelec and Dozet, 1997). The succession of cherty limestone at Dovško currently has no lithostratigraphic designation. The section is composed of grey, brownish grey cherty limestone layers with the thickness of 10 to $50 \mathrm{~cm}$, and filaments can be distinguished at certain levels. The cherty limestones are to the north covered by Tertiary rocks. To the south, they are in fault contact with Middle Triassic carbonates (Buser, 1978). The lower part of the succession is exposed by a road cut and the upper part can be followed in the adjacent creek. The series is approximately $65 \mathrm{~m}$ thick, without counting two partially covered and slightly tectonized intervals where the thickness is unclear (Fig. 2).

\section{MATERIAL AND METHODS}

Sampling was carried out in two phases. In the first phase, 26 samples (D1 to D26) were taken for conodont biostratigraphic study in order to get a general idea about the age of the section. Based on the results of the first sampling, the second sampling campaign was carried out, during which another 29 samples (D10A to D26B) were taken from the interval between sample D10 (at ca. $22 \mathrm{~m}$ above the base) and the top of the section for conodonts and microfacies analysis. Samples of the second sampling marked with letter ' $A$ ' correspond to the same sample numbers of the first sampling. Conodont samples with approximate weight of $3 \mathrm{~kg}$ were collected. Rocks were extracted using standard dissolution technique of diluted (10\%) acetic acid. Residues were enriched by density separation with bromoform and fossils were picked manually. Conodonts were recovered from every sample, and fish teeth were found beside them. Laboratory work, preparation of the thin sections and SEM imaging of the conodonts were done by the JEOL JSM 6490LV scanning electron microscope at the Geological Survey of Slovenia. The materials are deposited at the Geological Survey of Slovenia under inventory numbers 3530-3555, 36273635, 6060-6088 and abbreviated GeoZS.

The microfacies analysis was carried out on 34 thin sections of sizes $28 \mathrm{~mm} \times 47 \mathrm{~mm}$, prepared from 21 samples. Thin sections were stained with Alizarin S Red. Thin sections were investigated under the polarizing optical microscope. The samples are classified using terminology after Dunham (1962), modified by Embry and Klovan (1971).

\section{RESULTS}

The color of conodont elements is brownish grey to grey corresponding to the CAI value of 2-2.5. Fish teeth are yellowish white in color. Conodonts occur in high numbers (mainly between 80 and 300 specimens) in most of the samples. Sample D17A yielded over 300 specimens, whereas only a few specimens were found in samples D21B, D24A and D24C.

\subsection{Conodont Biostratigraphy}

The lower part of the Dovško succession below the sample D8 is assigned to the Lacian 1 based on the conodont assemblage of Metapolygnathus mazzai, Ancyrogondolella quadrata and A. rigoi (Fig. 2). The last occurrence (LO) of Me. mazzai is within this interval. One specimen of $A$. triangularis is present in sample
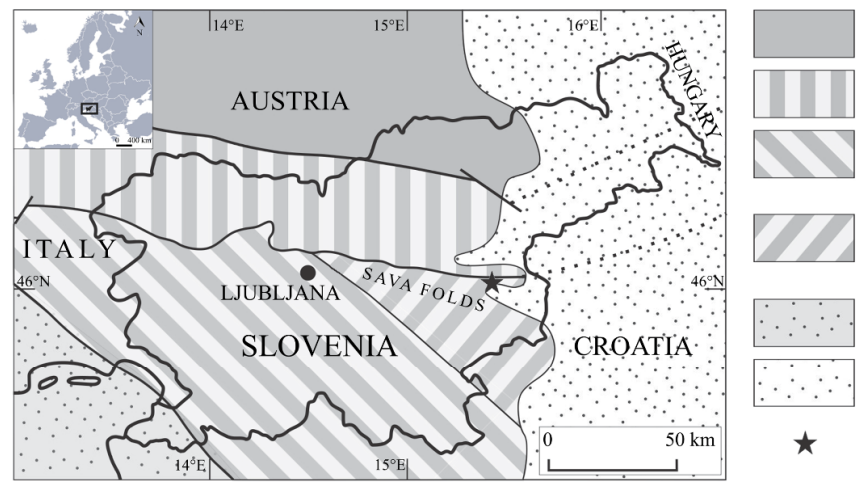

Eastern Alps

Southern Alps

External Dinarides

Transitional region

between External and

Internal Dinarides

Adriatic-Apulian foreland

Pannonian Basin

Dovško locality

Figure 1. Simplified geological map showing the main structural units and the location of the Dovško Section (black star) of Slovenia. Inset map shows the position of Slovenia. 


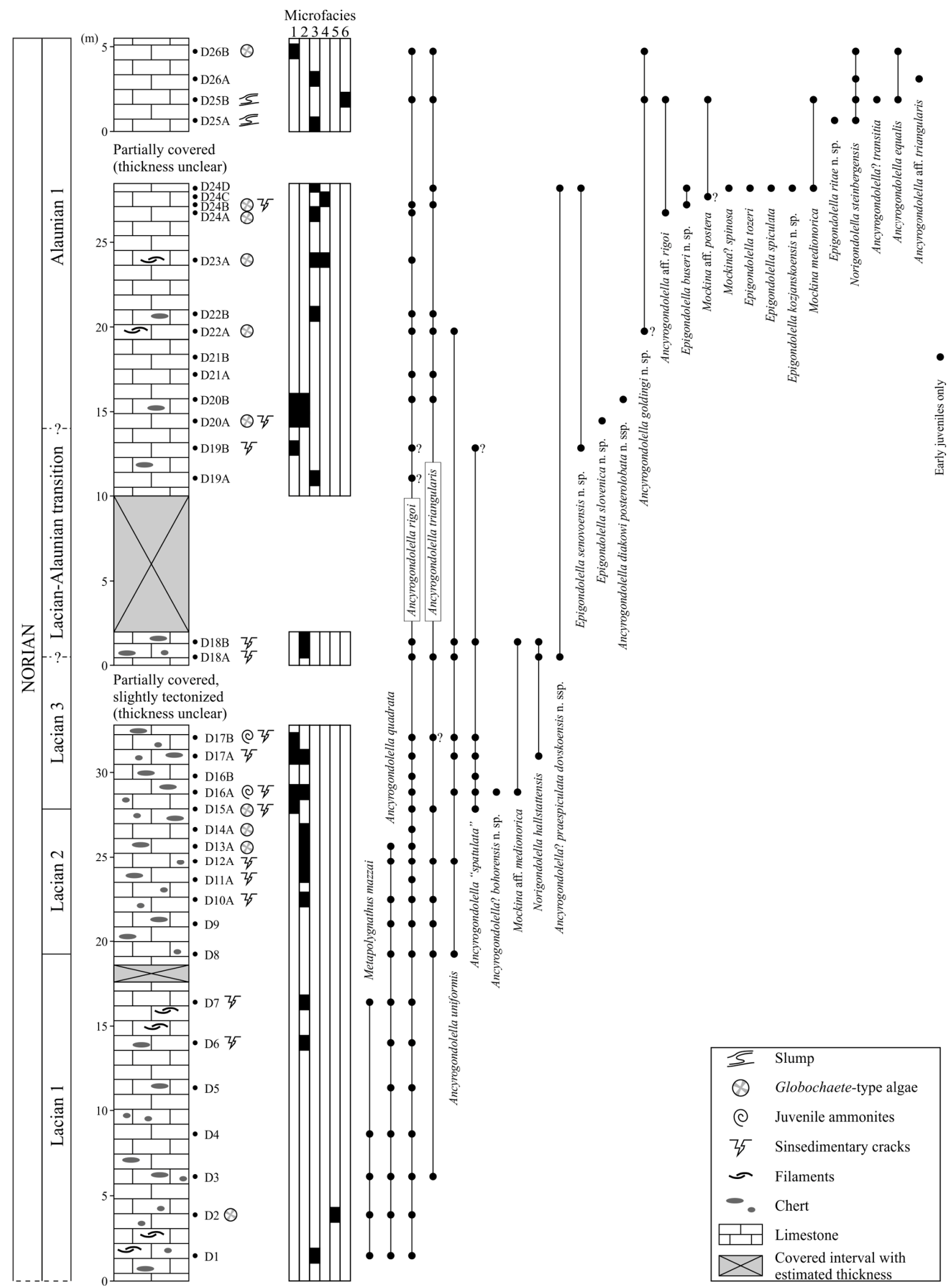

Figure 2. Stratigraphic log of the Dovško Section showing the distribution of microfacies types and the ranges of conodonts. Scale is in meters.

D3, but this species becomes abundant from sample D8 upwards, which marks the base of the Lacian 2. In this part of the section the first occurrence (FO) of A. uniformis and the LO of $A$. quadrata are recorded. The base of the Lacian 3 is indicated by the FO of $A$. "spatulata" in sample D15A. The age is confirmed also by the mass occurrence of Norigondolella hallstattensis in this interval. In the lower part of the Lacian 3 in sample D16A Ancyrogondolella? bohorensis n. sp. and Mockina aff. medionorica are documented. The lower boundary of the LacianAlaunian transitional interval is tentatively placed at sample 
D18A with the FO Ancyrogondolella? praespiculata dovskoensis n. ssp. This part of the section is characterized by the LO of A. "spatulata", Mockina aff. medionorica and N. hallstattensis, the FO of Epigondolella senovoensis n. sp., and the presence of A. rigoi, A. triangularis and $A$. uniformis.

The interval from D20A onwards is Alaunian 1 in age. Samples D20A and D20B from the lower part of this interval yielded specimens of E. slovenica n. sp. and Ancyrogondolella diakowi posterolobata $\mathrm{n}$. ssp. In sample D21B only early juvenile conodonts were found. A broken specimen supposedly of $A$. goldingi $\mathrm{n}$. sp. was recovered from sample D22A, in which the LO of A. uniformis is documented. In the short interval from D24A to D24D the appearance of several species is recorded, namely Ancyrogondolella aff. rigoi, E. buseri n. sp., Mockina aff. postera, Mockina? spinosa, E. tozeri, E. spiculata, E. kozjanskoensis n. sp. and Mo. medionorica. The LO of Ancyrogondolella? praespiculata dovskoensis $\mathrm{n}$. ssp. and E. senovoensis $\mathrm{n}$. sp. is in sample D24D. The uppermost interval of the section, between samples D25A and D26B, is characterized by the FO of E. ritae n. sp., N. steinbergensis, Ancyrogondolella? transitia, A. equalis and Ancyrogondolella aff. triangularis, as well as the presence of $A$. rigoi, A. triangularis, A. goldingi n. sp., Ancyrogondolella aff. rigoi, Mockina aff. postera and Mo. medionorica.

\subsection{Microfacies Analysis}

The investigated samples fall into six microfacies types, presented in Fig. 3 and summarized in Table 1. Microfossils from thin sections are shown in Fig. 4. Most samples were classified as radiolaria and filament-bearing mudstone to sparse wackestone (MF1), radiolarian wackestone to packstone (MF2), or filament wackestone to packstone (MF3; Table 1). These microfacies types are characterised by micritic mud matrix and contain basically the same grain types - the radiolarians and filaments (thin-shelled bivalves), which vary in proportions. Calcified radiolarians are dominated by Spumellaria, whereas Nasellaria are less numerous. Ammonites, small foraminifers (mostly elongated lagenids), ostracods, echinoderms, gastropods, globochaete algae, and holothurian sclerites are very rare. Some samples are locally dolomitized. Dolomitization ranges from growth of euhedral dolomite crystals within the matrix to pervasive dolomitization, which obscures the original texture of the rock. Except for sample D1 near the base of the section, the filament wackestone to packstone is restricted to sample D19A and higher. The other two MF types are present throughout the section but dominate up to sample D18B.

Other microfacies types occur sporadically and mostly in single samples. Microfacies type 4 (filament packstone with intraclasts) almost completely consists of densely packed filaments among which are squeezed some micritic intraclasts. In MF type 5 (filament-intraclastic packstone-grainstone), a large part of micritic matrix was winnowed away, and the rock consisting mostly of well sorted peloids (micritic intraclasts). Filament-intraclastic packstone (MF5) is the coarsest of the recorded MF types. Up to 2 $\mathrm{mm}$ large intraclasts and filaments predominate.

Throughout the section, the samples show signs of bioturbation and various degrees of small-scale slumping or beginnings of brecciation. Small neptunian dykes were observed in samples D17, D18 and D25. Dykes are partly filled with calcite cement and partly by micrite, intraclasts and other grains found in the surrounding rock. The infill thus does not seem to be younger than the rest of the sediment.

\section{DISCUSSION}

Paleogeographic reconstructions of the extent of the Slovenian Basin bear important implications to studies of regional tectonic movements and deformations, and positions of other terranes in the Alpine region, but its size, position, and connections are still unsatisfactorily resolved (Gale et al., 2019) The extent of the Slovenian Basin during the Norian and Rhaetian was determined for western Slovenia from the continuous exposures of the "Bača Dolomite" and/or of the Slatnik Formation (Rožič et al., 2013; Buser, 2009, 1986). Upper Triassic basinal succession is more poorly researched towards the east (Jarc et al., 2017; Ogorelec and Dozet, 1997), and close to the Slovenian-Croatian border. The exposures of the Upper Triassic basinal formations are covered by Neogene sediments and sedimentary rocks of the central Paratethys (Buser, 2009). The Dovško Section of lithostratigraphically yet unassigned cherty limestones is thus among the easternmost exposures of the Slovenian Basin.

The precise biostratigraphic dating of the Dovško succession is, without doubt, an important task in order to enable comparative studies with western Slovenian sections, which may lead to a better understanding of basin geometry and development through the Late Triassic. The lack of ammonoids in the Dovško Section truly means a hardship, because the Lacian-Alaunian (lower-middle Norian) boundary is not yet well defined with conodonts. Some species, such as Norigondolella hallstattensis and $N$. steinbergensis suggest an approximate age, as the ranges of these taxa are quite well calibrated with ammonoids, mainly in Alpine sections (e.g., Krystyn et al., 2009; Krystyn, 1980). Interpretations have to be made with care, however, because the presence of norigondolellids in a section is environmentally controlled (Trotter et al., 2015), so their first and last occurrences (FOs and LOs) may not necessarily be close to their first and last appearance datum (FADs and LADs).

Samples from the lowermost part of the section yielded only Ancyrogondolella quadrata, A. rigoi and Metapolygnathus mazzai. Although these taxa are known also from the upper Tuvalian (Rigo et al., 2018), a Carnian age of the lowermost part of the Dovško Section is unlikely due to the absence of any diagnostic Carnian species, and the Carnian-Norian boundary interval was not documented either. The LO of Me. mazzai in the Lacian 1 is also documented in other areas of the former Tethys such as in Hungary (Karádi et al., 2013) and in Italy (Mazza et al., 2012), as well as in the eastern Pacific even if Orchard (2014) included this species in the Primatella mersinensis population. The FO of $A$. triangularis is often used to mark the base of the Lacian 2 (e.g., Krystyn et al., 2009; Gawlick and Böhm, 2000). Kozur (2003) and Channell et al. (2003) differentiated an Epigondolella triangularis-Norigondolella hallstattensis Zone for the upper half of the Lacian (i.e., upper half of Lacian 2 and Lacian 3) noting that the FAD of $N$. hallstattensis is just below the FAD of typical A. triangularis. This statement is not supported by conodonts of the Dovško Section where the FAD of A. triangularis is docu- 
mented below the occurrence of $N$. hallstattensis, even if the FO of $N$. hallstattensis does not correspond to its real FAD. Data from other areas, such as Sicily (Mazza et al., 2012) or the Hallstatt region (Krystyn et al., 2009) likewise support an earlier appearance of $A$. triangularis, whereas the range of $N$. hallstattensis correlates with the uppermost paulckei Zone to the top of the magnus Zone, i.e., uppermost Lacian 2 and Lacian 3 (Krystyn et al., 2009; Krystyn, 1980). The LO of A. quadrata is within the Lacian 2 in the studied succession, although specimens of ambiguous affinity having rectangular, mostly unornamented, sub- parallel margins and bifid keel end are present throughout the section. Nevertheless, the revision of the Lacian ancyrogondolellids is beyond the scope of this study.

The base of the Lacian 3 in the Dovško Section was placed at the FO of $A$. "spatulata" following the Alpine practice (e.g., Krystyn et al., 2009; Gawlick and Böhm, 2000; Krystyn, 1980) where the FAD of this species is correlated with ammonites of the magnus Zone. The species name is, however, placed in quotation marks herein, due to the evident differences from the holotype figured by Hayashi (1968). The original illustration
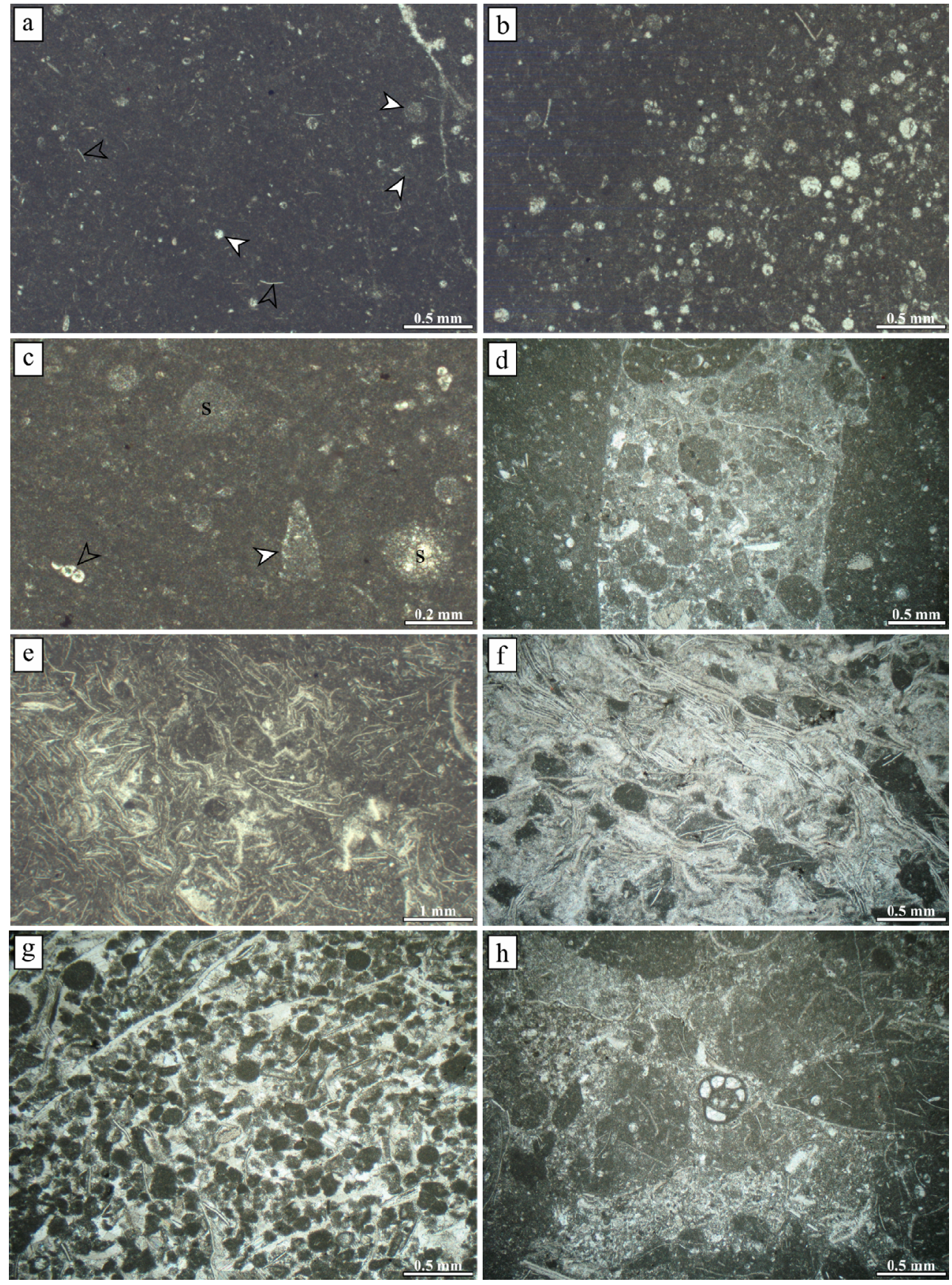

Figure 3. Microfacies from the Norian cherty limestone at Dovško. a. Mudstone to sparse wackestone with radiolarians (white arrowhead) and filaments (empty arrowhead); sample D20. b. Radiolarian wackestone; sparse wackestone in the upper left corner, passing into dense wackestone on the lower right side of the picture; sample D12. c. Radiolarians; S. Spumellaria; white arrowhead. Nasselaria; and globochaete algae (empty arrowhead) within radiolarian wackestone; sample D20. d. Neptunian dyke penetrating radiolarian wackestone-packstone; sample D18. e. Filament wackestone and packstone; sample D22. f. Filament packstone with intraclasts; sample D23. g. Filament-intraclastic grainstone; sample D2. h. Filament-intraclastic packstone; Variostoma (a foraminifer) is positioned in the center; sample D25. 
shows a P1 element with sub-circular outline that is rather spoon-shaped than spatula-shaped. The free blade is also longer than in A. "spatulata", the cusp is the last denticle of the carina and the keel termination is squared instead of bifurcated. The holotype might represent an early adult growth stage based on the size, however the bifurcation of the keel and the appearance of the posterior carina should already be visible at that stage. The general characteristics of the holotype resemble more faunas of the Carnian-Norian boundary interval or the lower Lacian 1 and rather than those of the Lacian 3, which is confirmed also by the stratigraphic position of the specimen figured by Mazza et al. (2012, pl. 6, fig. 8) from the Pizzo Mondello Section. This

Table 1 Description of microfacies (MF) types from the Norian cherty limestone at Dovško

\begin{tabular}{|c|c|c|}
\hline Microfacies type & Description & Figure \\
\hline $\begin{array}{l}\text { Radiolaria and filament-bearing } \\
\text { mudstone-sparse wackestone } \\
\text { (MF1) }\end{array}$ & $\begin{array}{l}\text { Mudstone to sparse wackestone contains calcified radiolarians (mostly globular Spumellaria) and } \\
\text { filaments in up to } 10 \% \text {. Foraminifers (Duostominidae, nodosariid lagenids), echinoderms, ostracods, } \\
\text { juvenile ammonoids, holothurians (type Theelia) and globochaete algae are only sporadically present. }\end{array}$ & $3 a$ \\
\hline $\begin{array}{l}\text { Radiolarian wackestone- } \\
\text { packstone } \\
\text { (MF2) }\end{array}$ & $\begin{array}{l}\text { Bioturbation is very pronounced and is the cause for the highly heterogenous composition of the rock. } \\
\text { Radiolarians represent } 20 \%-30 \% \text { of the rock, but are locally even more abundant, forming packstone } \\
\text { texture. Globular Spumellarias predominate over rare Nassellaria. Radiolarians are calcified. Subor- } \\
\text { dinate is thin-shelled bivalves ( } 0.5 \%-5 \% \text { of the rock). Ostracods, globochaete algae, holothurian } \\
\text { sclerites (type Theelia), microgastropods, small nodosariid or other lagenid foraminifers (Lenticulina } \\
\text { sp.) are sporadically present. A small neptunian dyke was recorded in sample D18. The dyke is filled } \\
\text { with intraclastic packstone. The intraclasts correspond to the radiolarian wackestone that the dyke is } \\
\text { penetrating. They are poorly sorted, rounded to angular. The intermediate space is filled with partly } \\
\text { washed micrite. A few patches of drusy mosaic spar occur locally. A few fossils are also present } \\
\text { within the dyke: small filaments, a foraminifer Lenticulina, and echinoderm plates. }\end{array}$ & $3 b-3 d$ \\
\hline $\begin{array}{l}\text { Filament wackestone-packstone } \\
\text { (rarely floatstone-rudstone) } \\
\text { (MF3) }\end{array}$ & $\begin{array}{l}\text { The rock is heterogenous due to bioturbation. Thin-shelled bivalves are more common to the point } \\
\text { when they locally become rock-forming. Bivalves are in places strongly fragmented, whereas in other } \\
\text { cases up to } 2 \mathrm{~cm} \text { long valves are preserved (floatstone). Micritic matrix is locally (below or in be- } \\
\text { tween the valves) washed-out. A drusy-mosaic calcite cement is thus locally also present. Calcified } \\
\text { radiolarians are usually much less common than in other two microfacies types, but locally represent } \\
\text { up to } 10 \% \text { of the rock. Very rare are foraminifers (Tolypammina, "Trochammina" jaunensis Brönni- } \\
\text { mann and Page, ?Endotriada tyrrhenica Vachard, Martini, Rettori and Zaninetti, ?Hydrania dulloi } \\
\text { Senowbari-Daryan, small nodosariid and other lagenids, small agglutinated forms), juvenile ammon- } \\
\text { oids. Small micritic pellets are locally present, but not in great amounts. }\end{array}$ & $3 e$ \\
\hline $\begin{array}{l}\text { Filament packstone with } \\
\text { intraclasts } \\
\text { (MF4) }\end{array}$ & $\begin{array}{l}\text { Filaments are densely packed together and in long contacts, forming perhaps } 85 \%-90 \% \text { of the rock. } \\
\text { Among the filaments are dispersed subangular to subrounded isometric micritic intraclasts (mudstone } \\
\text { and sparse filament-radiolarian wackestone). Intraclasts display some rotation and deformation, } \\
\text { probably due to compaction. Their average size is } 0.4 \mathrm{~mm} \text {. Very rare are unfragmented nodosariid } \\
\text { lagenids and echinoderm plates. Micritic matrix is subordinate, filling } 5 \% \text { of the space. Echinoderm } \\
\text { plates are overgrown by syntaxial rim cement. }\end{array}$ & $3 \mathrm{f}$ \\
\hline $\begin{array}{l}\text { Filament-intraclastic packstone- } \\
\text { grainstone } \\
\text { (MF 5) }\end{array}$ & $\begin{array}{l}\text { The texture is heterogenous, with gradual transitions between packstone and grainstone on one side } \\
\text { and into radiolaria and filament wackestone (described above). Grains represent } 50 \%-60 \% \text { of the } \\
\text { rock. The intergranular space is filled with micritic matrix and drusy mosaic calcite cement. The } \\
\text { grains are mostly in point contacts. The most abundant grains are micritic peloids ( } 90 \% \text { of grains). } \\
\text { They are moderately to very well sorted, ranging from subangular to well rounded. Most are isomet- } \\
\text { ric in shape, and some appear perfectly circular in transect. Peloids are interpreted as micritic intra- } \\
\text { clasts, but all or part of the circular ones could in fact be completely micritized spumellarian radio- } \\
\text { larians. The rest of the grains are bioclasts. Among these, filaments are the most conspicuous. They } \\
\text { show no orientation. The reliably identifiable radiolarians are calcified, but some have micritized } \\
\text { outlines. Spumellarians predominate. Very rare are echinoderm plates and foraminifers (fragmented } \\
\text { nodosariid lagenids). }\end{array}$ & $3 g$ \\
\hline $\begin{array}{l}\text { Filament-intraclastic packstone } \\
\text { (MF6) }\end{array}$ & $\begin{array}{l}\text { Intraclasts on average represent } 40 \% \text { of the area. They are } 1-2 \mathrm{~mm} \text { in size. Mudstone, radiolarian } \\
\text { wackestone and filament wackestone predominate, beside rare filament-intraclastic packstone clasts. } \\
\text { They are subangular to subrounded, isometric to elongated. The rest of the rock is mostly micritic } \\
\text { mudstone, densely packed with filaments. These range from strongly fragmented to longer pieces of } \\
\text { shells, mostly lacking uniform orientation, except in small patches. Valves are singular or in pairs. } \\
\text { Foraminifers (Variostoma sp., miliolid foraminifera, Pseudonodosaria sp.), echinoderm plates and } \\
\text { microgastropods are volumetrically unimportant. Echinoderm plastes are overgrown by syntaxial rim } \\
\text { calcite cement. }\end{array}$ & $3 \mathrm{~h}$ \\
\hline
\end{tabular}



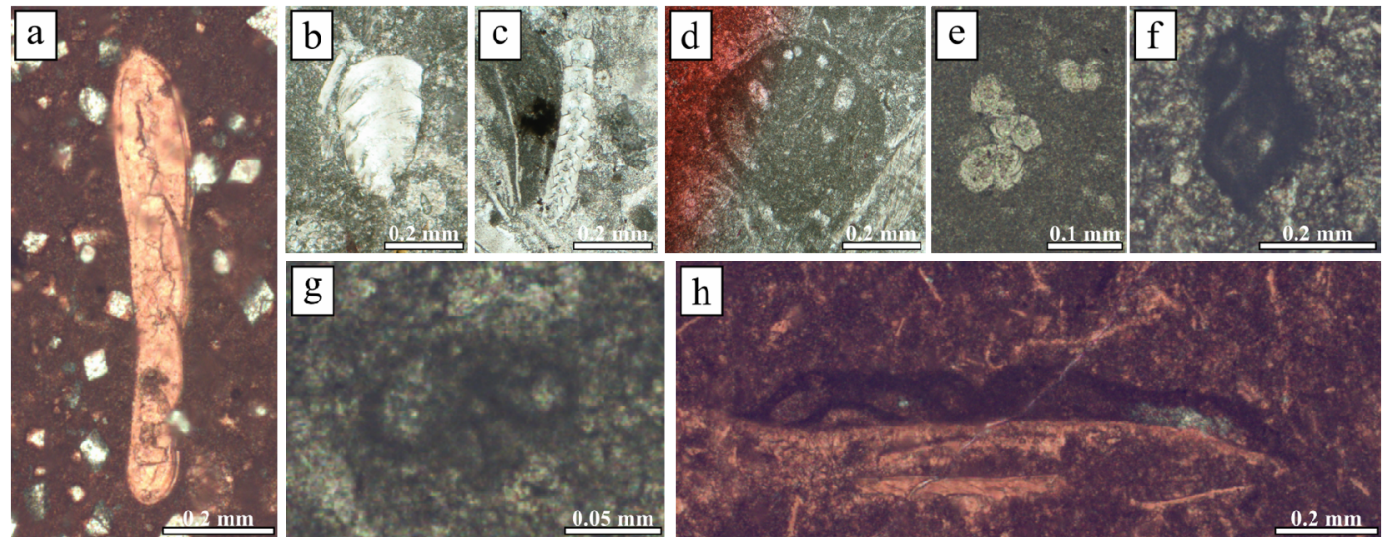

Figure 4. Microfossils from the Norian cherty limestone at Dovško. a. A lagenid foraminifer; sample D10. b. Pseudonodosaria sp.; sample D25. c. Nodosariid Lagenida; sample D23. d. Variostoma sp. (V. cochlea Kristan-Tollmann or V. helicta Tappan); sample D25. e. Globochaete algae; sample D20. f. ?Hydrania dulloi Senowbari-Daryan; sample D25. g. "Trochammina” jaunensis Brönnimann and Page. h. Foraminifer Tolypammina sp.; sample D26.

suggests that Ancyrogondolella "spatulata" of the Lacian 3 is not identical with the species established by Hayashi (1968), but a different taxon. Since the name is widely used for conodonts of the magnus Zone, we retained the nomenclature for the time being to enable easier correlation. In the future, however, these taxa need to be revised.

The first specimens, assigned here to Ancyrogondolella? bohorensis $\mathrm{n}$. sp., that show transitional characters towards middle Norian faunas appear in sample D16A, still in the lower part of the Lacian 3, although they remain quite rare at this level. The slight forward shifting of the pit in front of the platform midlength, the prolongation of the posterior carina and the posterior prolongation of the keel are morphological developments that become dominant in the Alaunian 1 (Karádi, 2021). Notable is the asymmetry of the keel termination with the gradual loss of the secondary lobe, a feature that was also recognized by Kozur (1989a) and Orchard (2018). A transitional interval between the Lacian and the Alaunian is marked between samples D18A and D20A due to the absence of ammonoids. A large part of the Lacian-Alaunian transition is unfortunately covered, but the LO of $N$. hallstattensis and A. "spatulata" and the FO of Ancyrogondolella? praespiculata dovskoensis n. ssp. and Epigondolella senovoensis $\mathrm{n}$. sp. suggest that the Lacian-Alaunian boundary can be found somewhere within this interval. The FO of Ancyrogondolella? praespiculata in North America is likewise documented in the lower-middle Norian transition (Orchard, 2018). The base of the Alaunian in the Dovško Section is placed at sample D20A, because taxa (e.g., E. slovenica n. sp.) with Alaunian-type morphologies start to be abundant at this level. They reach the highest diversity and dominate over the broad Lacian-type ancyrogondolellids in sample D24D, where the faunal turnover starts, although sub-triangular specimens with bifid keel remain present till the top of the section. The uppermost part of the succession (from samples D25A to D26B) is unequivocally Alaunian in age based on the large numbers of $N$. steinbergensis. Important is the presence of E. ritae n. sp. in sample D25A from a biostratigraphic point of view, because this species allows correlation with the Alaunian 1 of the Hallstatt region of Austria. A collection of ammonoids of the bicrenatus Zone was displayed in an online blog by Spatzenegger (2011) that comprise illustrations of the accompanying conodont assemblage from the fossiliferous bed. This fauna also includes $N$. steinbergensis (determined as Neogondolella navicula) and a specimen (determined as Metapolygnathus spatulatus spatulatus) that is identical with $E$. ritae $\mathrm{n}$. sp. established herein. It is likely that $E$. ritae n. sp. will be an important index form of the Alaunian 1.

The comparison of the conodont assemblage of the Dovško Section with that of other areas is difficult at this stage due to the scarcity of well documented faunas of this age. Only general observations can be made based on the studies by Orchard (2018, 1991a, b). The Lacian interval seems to be more or less similar both in North America and in the Tethys. The FO of A. triangularis is somewhat later in the eastern Pacific than in the western Tethys and A. rigoi is possibly more abundant in the latter region. Only rare records of Norigondolella hallstattensis are known from North America (Orchard, 2006, 1991b), but the stratigraphic range of the species seems to be the same as in the Tethys. A great difference is the LO of typical representatives of the genus Ancyrogondolella, which are no longer found after the Lacian in North America (Orchard, 2018), but the presence of posteriorly wide specimens with a bifid keel (A. rigoi, Ancyrogondolella aff. rigoi, A. triangularis, Ancyrogondolella aff. triangularis, A. goldingi n. sp.) also in the uppermost samples of the Dovško Section proves that species of this genus range up in the Alaunian in the Tethys. Likewise, a difference can be observed in the ranges of certain taxa, namely Ancyrogondolella aff. triangularis, Ancyrogondolella? transitia and A. equalis, which are found in the Lacian 3 and/or the lower-middle Norian transition of North America, but are documented in the Alaunian 1 of the Dovško Section. Interestingly, a gentle morphological separation between Tethyan and North American conodonts seems to start during the LacianAlaunian transition that affects the majority of the species at least in the middle and upper Norian. Species in the eastern Pacific appear to be more slender and narrower, developing a longer posterior carina than the same taxa in the western Tethys. This phenomenon, which does not apply for Lacian faunas, might be related to paleoecologic causes, but detailed studies on this topic have not yet been carried out.

The mud-dominated nature of MF types 1-3 in the Dovško Section and the almost complete predominance of pelagic and/or open-marine indicators (radiolarians, filaments, 
globochaete algae, ammonites) suggest deposition in an open-marine environment (Flügel, 2004). The change in facies assemblage, i.e., from MF1 and MF2-dominated succession into MF3-dominated part takes place in the covered part of the section between samples D18B and D19A, which corresponds to the Lacian-Alaunian transition and just precedes the proliferation of conodonts with Alaunian-type characters. The small neptunian dykes (Fig. 3d) recorded at this level (D17, D18) might also be related to a change in environment or basin geometry. The abundance of thin-shelled bivalves in the upper part of the section is difficult to explain. As a possible reason, we suggest some changes in oxygen level and/or the height of the oxygenated part of the water column (perhaps a better aeration of the basin). It could also be due to some other environmental factors, such as the change in temperature, or perhaps due to a change in position on the slope or the change of slope topography. Signs of incipient slumping and brecciations, as well as formation of neptunian dykes indicate mass-movements on a slightly inclined sea floor.

Filament packstone with intraclasts could represent redeposition of thin-shelled bivalves and rip-up clasts via some sort of mass-flow or currents. Filament-intraclastic packstone-grainstone (MF 4) and filament-intraclastic packstone (MF5) also suggest that, in minor amounts, mass flows also contributed to sedimentation. Filament-intraclastic packstone-grainstone might represent distal turbidites or grain flow deposits, as suggested by sorting of the grains, while filament-intraclastic packstone might be sediment of a small-scale debris flow. The intraclasts all derive from local environment, suggesting either low energy of these events, the absence of major perturbations at the basin's margins, or a distal position of the depositional area. The open- (and probably deeper-) marine nature of the sampled succession is supportive of the current interpretation about the extent of the Slovenian Basin (Rožič, 2016). The width of the basin, the morphology of its margins, the distance to the platform and the connection with other parts of the basin, however, cannot yet be guessed at due to the lack of information from the eastern part of the Slovenian Basin.

\section{CONCLUSIONS}

The detailed conodont biostratigraphic studies and microfacies analyses carried out on the Dovško succession are proven to be important in many aspects. The documentation of the diversity, morphological variability and temporal distribution of the conodont taxa allows an insight into the evolutionary trends that characterize the faunas allowing the fine subdivision of the Lacian to lower Alaunian interval. The development from Lacian-type morphologies to Alaunian-type features, which starts during the Lacian 3 and leads to a faunal turnover in the Alaunian 1 seem to coincide with environmental perturbations that manifest in the change of facial assemblage and the formation of neptunian dykes.

Future studies on the conodont assemblages of the Alpine region, including the reinvestigation of classic localities will enable calibration of the important events in conodont evolution with ammonoid zonation. This will confirm the biostratigraphic value of the new conodont taxa described herein from the Dovško Section, which is of great significance in the case of successions lacking ammonoids.
Our study contributes to the knowledge on the yet poorly understood paleogeography and development of the eastern part of the Slovenian Basin, which has an important role in geological studies of Slovenia and tectonic reconstructions of the broader western Tethys region.

\section{SYSTEMATIC PALEONTOLOGY}

Class Conodonta Pander, 1856

Order Ozarkodinida Dzik, 1976

Superfamily Gondolelloidea (Lindström, 1970)

Family Gondolellidae Lindström, 1970

Genus Ancyrogondolella Budurov, 1972

Type species: Ancyrogondolella triangularis Budurov, 1972

Description: The platform of this genus is generally broad, symmetrical or asymmetrical, and variably ornamented with high denticles. The length of the free blade is between $1 / 2$ and $1 / 3$ element length. The posterior carina is composed of one carinal node, only stratigraphically younger species may have a longer posterior carina. Presence of secondary carinae is common. The pit is centrally located below the platform, the keel is not prolonged and its end is usually strongly bifurcated. The lower margin of the elements in lateral view is mainly arched.

Comparison: Genus Metapolygnathus has an anteriorly shifted pit, a longer posterior carina and a keel that shows a posterior prolongation even if the termination is bifurcated. Genus Epigondolella has a single-lobed, posteriorly prolonged keel, a posterior carina of at least two nodes and a stepped or upturned lower margin. Compared to genus Ancyrogondolella, genus Mockina is generally smaller with narrower platform, a longer posterior carina and a single-lobed and posteriorly prolonged keel.

Ancyrogondolella? bohorensis $\mathrm{n}$. $\mathrm{sp}$.

Figs. 5/1-2

Derivation of name: Named after the Bohor Range of eastern Slovenia.

Holotype: The specimen in Fig. 5/1 (GeoZS 6066-1)

Type locality: Section along the Dovški Potok Stream at Dovško, near Senovo, eastern Slovenia.

Type stratum: Brownish grey, cherty limestone of Lacian 3 age.

Material: 2 specimens in 1 sample

Diagnosis: Conodont with an anteriorly narrower, posteriorly wider platform and rounded posterior end. Anterior margins bear denticles, the rest of the margins are weakly or not denticulated. A posterior carina of two nodes is present. The keel behind the nearly central pit has an asymmetrically truncated or forked end.

Description: This conodont species has a platform that is narrower in the anterior half and somewhat more expanded in the posterior half. The posterior end of the platform is rounded. The anterior margins bear three to four high denticles. The rest of the platform may have few low nodes, or can be unornamented. The free blade is between $1 / 2$ and $1 / 3$ element length. The blade is anteriorly high and descends gradually towards the cusp, which is undistinguished in size. The cusp is followed by a posterior carina composed of two nodes. The pit is located just in front of the center of the platform. The keel is posteri- 
orly prolonged, slightly asymmetric and can have a forked or truncated termination. The lower margin of the element is nearly straight in lateral view.

Comparison: Mockina matthewi has a biconvex platform and a rounded keel end. Mockina aff. medionorica has subparallel platform margins and a shorter posterior carina.

Remarks: This species is assigned here to genus Ancyrogondolella with question, for the same reasons Orchard (2018) marked the generic uncertainty of Ancyrogondolella? praespiculata. It has to be noted though, that several morphological characters (e.g., pit position, keel prolongation, length of posterior carina) of Ancyrogondolella? bohorensis n. sp. are transitional and resemble stratigraphically younger faunas.

Occurrence: Present in the lower part of the LacianAlaunian transition of the Dovško Section.

\section{Ancyrogondolella diakowi posterolobata n. ssp.}

Fig. $5 / 3$

Derivation of name: Name refers to the posterior lobe of the platform, pronounced by the indentation of the posterior margin and the uneven development of the two sides of the element.

Holotype: The specimen in Fig. 5/3 (GeoZS 6075-1)

Type locality: Section along the Dovški Potok Stream at Dovško, near Senovo, eastern Slovenia.

Type stratum: Brownish grey, cherty limestone of Alaunian 1 age.

Material: 1 specimen in 1 sample

Diagnosis: Conodont with an anteriorly narrow, posteriorly asymmetrically expanded platform, an indentation at the posterior margin and denticles all over the platform margins. A posterior carina of two nodes and secondary carinae are present. The pit is in slightly anterior position and the keel end is bifid.

Description: This subspecies of $A$. diakowi has a subtriangular platform. The narrow anterior half has parallel margins and the posterior half is widely expanded with the internal lobe of the platform being more developed. The anterior margins bear three high denticles and the lateral and posterior margins are also strongly ornamented with ridge-like denticles. A characteristic indentation is present at the middle of the posterior margin, and two smaller at the postero-lateral corners of the platform. The free blade is between $1 / 2$ and $1 / 3$ unit length. The blade is highest around the platform-blade junction and descends gradually towards the anterior and the posterior. The cusp is undistinguished in size and it is followed by two carinal nodes. From the second carinal node two secondary carinae are developed in the direction of the postero-lateral corners. The pit is situated somewhat in front of the platform midlength. The keel is widely bifurcated behind the pit. In lateral view the element has an arched lower margin.

Comparison: The typical indentation of the posterior platform margin distinguishes Ancyrogondolella diakowi posterolobata n. ssp. from all other Ancyrogondolella taxa with sub-triangular or triangular outline, such as $A$. triangularis, $A$. rigoi and $A$. goldingi n. sp. Additionally, A. triangularis can have a more expanded posterior platform, $A$. rigoi lacks ornamentation on the lateral and posterior margins, and $A$. golding $i$ n. sp. bears two pronounced, ridge-like denticles in the middle of the posterior margin.

Remarks: This conodont is regarded here as a subspecies of $A$. diakowi, because such a typical outline of the posterior margin has never been documented in any other Norian taxa. However, $A$. diakowi described and figured by Orchard (2018) has a less expanded posterior platform and a longer posterior carina. Ancyrogondolella diakowi posterolobata $\mathrm{n}$. ssp. seems to be an intermediate form between A. triangularis and A. diakowi.

Occurrence: Present in the lower part of the Alaunian 1 of the Dovško Section.

Ancyrogondolella equalis Orchard, 2018

Figs. 5/4-5

pars 2013 Epigondolella uniformis Orchard, 1991, Karádi et al., pl. 3, fig. 10 (only).

2018 Ancyrogondolella equalis n. sp., Orchard, p. 172; pl. 1, figs. 15-19.

Material: 5 specimens in 2 samples

Description: This conodont has a symmetrical platform with parallel margins and rectangular outline. The anterior margins bear two to three large denticles that are elongated towards the carina. Strong, denticles are present on the rest of the platform margins. One or both postero-lateral corners have a distinct, ridge-like denticle that developed in the direction of the center of the platform. The free blade is between $1 / 2$ and $1 / 3$ element length, but closer to $1 / 3$. The blade is high anteriorly and descends gradually posteriorly. The cusp is followed by a posterior carina of two nodes. The pit is located slightly in front of the middle of the platform. The keel is moderately prolonged posteriorly, but has a bifurcated termination. The element has a stepped lower profile in lateral view.

Comparison: Ancyrogondolella uniformis has a shorter platform and a posterior carina composed only of one node. The platform of Ancyrogondolella aff. triangularis is subtriangular and its keel end is asymmetrically bifid. Epigondolella ritae $\mathrm{n}$. $\mathrm{sp}$. has a narrower, obliquely truncated platform and a squared keel end.

Remarks: The specimens of the Dovško Section differ from the North American representatives in their shorter platform and shorter posterior carina, however, this might be related to paleoecologic variance.

Occurrence: Present in the Alaunian 1 of the Dovško Section. Known from the Lacian-Alaunian transitional interval of British Columbia, Canada (Orchard, 2018) and the Csővár area, Hungary (Karádi et al., 2013).

Ancyrogondolella goldingi $\mathrm{n}$. sp.

Figs. 5/6-7

Derivation of the name: In honor of Martyn Golding, Geological Survey of Canada, for his contribution to the knowledge of Triassic conodonts.

Holotype: The specimen in Fig. 5/6 (GeoZS 6088-1)

Type locality: Section along the Dovški Potok Stream at Dovško, near Senovo, eastern Slovenia.

Type stratum: Brownish grey, cherty limestone of Alaunian 1 age.

Material: 3 specimens in 3 samples

Diagnosis: Conodont with an anteriorly narrow, posteri- 
orly expanded platform that has denticles on the anterior margin and a denticle pair in the middle of the posterior margin. A short posterior carina of one node and secondary carinae are present. The lower side has a pit in central position and a keel with bifid termination.

Description: This species is characterized by a platform that is narrow in the anterior half and widely expanded in the posterior half. The platform margins are sub-parallel both in the anterior and in the posterior half. The posterior platform margin is straight. The anterior margins bear three to four large denticles, which are often elongated in direction of the carina. Few lower denticles may be present on the lateral margins, and two rigde-like denticles are always present in the middle of the posterior margin. The free blade is short, it is between $1 / 3$ and $1 / 4$ element length. The blade is anteriorly high and it descends gradually towards the cusp, which is undistinguished in size. The posterior carina consists of one node behind the cusp from where secondary carinae develop in the direction of the postero-lateral corners. The pit is centrally located and the keel has a pronounced bifurcation behind it. The lower margin in lateral view is slightly arched.

Comparison: Ancyrogondolella rigoi has a more triangular platform that has ornamentation only on the anterior margins. Ancyrogondolella aff. rigoi has weekly denticulated lateral and posterior platform margins, but lacks the prominent denticle pair in the middle of the posterior margin. Ancyrogondolella diakowi posterolobata $\mathrm{n}$. ssp. has a typical indentation on the posterior margin that is missing in A. goldingi $\mathrm{n}$. sp.

Remarks: The specimen from the Csővár borehole has a third, lower denticle on the posterior margin and it seems to come from a stratigraphically older level than the specimens of the Dovško Section. However, the exact range of $A$. goldingi $\mathrm{n}$. $\mathrm{sp}$. is not yet known, and the outline and denticulation of the platform suggest the assignment of the Csővár specimen to this new species.

Occurrence: Present in the Alaunian 1 of the Dovško Section. Known from the Lacian 1 of the Csővár borehole, Hungary (Fig. 5/7).

Ancyrogondolella? praespiculata dovskoensis n. ssp.

Figs. 5/8-10

Derivation of name: Named after the type locality.

Holotype: The specimen in Fig. 5/10 (GeoZS 6070-1)

Type locality: Section along the Dovški Potok Stream at Dovško, near Senovo, eastern Slovenia.

Type stratum: Brownish grey, cherty limestone of uppermost Lacian 3 age.

Material: 3 specimens in 2 samples

Diagnosis: Conodont that has a biconvex platform with a gently pointed end and ridge-like denticles on the margins. A posterior carina of two to three nodes is present. The pit is in anterior position with respect to the platform midlength, the keel has two short, asymmetrically developed lobes.

Description: The platform has a biconvex outline with the internal side being more rounded than the external side. The posterior margin has a gentle tip shifted towards the external side. Two to three ridge-like denticles are present on the anterior platform margins elongated towards the carina. The rest of the platform margins bear lower, but likewise ridge-like denticles. A node is present at the posterior tip of the platform. The free blade is $1 / 3$ unit length, the blade is high in the anterior part and descends gradually towards the cusp. The cusp is small and it is followed two to three larger nodes of the posterior carina. The carinal axis of the element has a gentle, but characteristic sinuous appearance. The pit is forward shifted in front of the platform midlength. The keel is posteriorly prolonged, asymmetric due to the two unequally developed lobes from which the longer one projects towards the posterior tip of the platform. In a few specimens the secondary lobe is significantly reduced (e.g., Fig. 5/8). The element has a slightly stepped lower margin in lateral view.

Comparison: Epigondolella spiculata has a narrower platform with the posterior part of the external side being more angular.

Remarks: This conodont is distinguished here as a subspecies of Ancyrogondolella? praespiculata, because the denticles of the platform margins are ridge-like and not conical like in the specimens from North America (Orchard, 2018, pl. 3, figs. 1-6).

Occurrence: Present in the Lacian-Alaunian transition (and Alaunian 1?) of the Dovško Section.

Ancyrogondolella quadrata (Orchard, 1991a)

Fig. 5/11

pars 1991a Epigondolella quadrata n. sp., Orchard, p. 311 ; pl. 2, figs. 1-3, 7-9 (only).

pars 2003 Epigondolella abneptis (Huckriede), Channell et al., figs. A2/31, 32, 36 (only); figs. A3/8, ?18 (only).

pars 2003 Epigondolella primitia Mosher, Channell et al., fig. A2/20 (only).

pars 2008 Epigondolella quadrata (Orchard), Celarc and Kolar-Jurkovšek, fig. 7/3 (only).

2012 Epigondolella quadrata Orchard, 1991b, Mazza et al., p. 106, 108; pl. 5, figs. 2-10.

pars 2013 Epigondolella quadrata Orchard, 1991, Karádi et al., pl. 1, fig. 1 (only); pl. 2, figs. 9, 19; pl. 3, fig. 2.

2014 Epigondolella quadrata Orchard, Orchard, p. 55-57; figs. 40/10-18, 19-27.

2015 Epigondolella cf. E. quadrata (Orchard), Gale et al., fig. $6 / 4$.

2016 Epigondolella quadrata Orchard, 1991, Karádi et al., pl. 1, fig. 3 .

Material: More than 30 specimens in 12 samples

Description: This conodont has a rectangular platform with parallel margins. The anterior platform has two to three large denticles, whereas the rest of the platform is unornamented. The free blade is long, between $1 / 2$ and $1 / 3$ element length, but closer to $1 / 2$. The blade is anteriorly high and descends gradually towards the cusp, which is followed by one carinal node. The pit is centrally located and the keel is widely bifurcated behind it. The element has an arched profile.

Comparison: Metapolygnathus mazzai has a longer platform and a longer posterior carina of two denticles. Also its keel is prolonged behind the pit. Ancyrogondolella equalis has denticles all over the platform margins and the posterior carina is longer than that of A. quadrata. Ancyrogondolella rigoi has a posteriorly expanding platform. 
Occurrence: Present in the Lacian 1-2 of the Dovško Section. Known from the Lacian of North America (e.g., Orchard, 2014, 1991a), Hungary (e.g., Karádi et al., 2016, 2013), Slovenia (e.g., Gale et al., 2015; Celarc and Kolar-Jurkovšek, 2008) and Slovakia (Channell et al., 2003), and the higher Tuvalian 3 to lower Alaunian of Italy (Mazza et al., 2012).

Ancyrogondolella rigoi (Kozur) in Noyan and Kozur (2007) Figs. 5/12-13

pars 2003 Epigondolella abneptis (Huckriede), Channell et al., figs. A2/27, 30, 33 (only).

2007 Epigondolella rigoi Kozur n. sp., Noyan and Kozur, p. 167; figs. 6.2-6.5.

2007 Epigondolella rigoi Kozur n. sp., Moix et al., p. 293.

2012 Epigondolella rigoi Noyan and Kozur, 2007, Mazza et al., p. 108; pl. 6, figs. 1-7.

pars 2013 Epigondolella rigoi Kozur, 2007, Karádi et al., pl. 1, figs. 2, 11, 12 (only); pl. 2, figs. 2, 5, 8, 20; pl. 3, figs. 3, 5.

2018 Epigondolella rigoi Kozur in Noyan and Kozur (2007), Karádi, p. 162; pl. 1, fig. 5.

Material: More than 50 specimens in 32 samples

Description: This conodont has a sub-triangular, often asymmetric platform with two to three high denticles on the anterior margins and smooth lateral and posterior margins. The free blade is between $1 / 2$ and $1 / 3$ element length. The blade is high in the anterior part and gradually gets lower towards the posterior. The cusp is small and it is followed by one, mainly larger carinal denticle. Secondary carinae may develop behind this large denticle. The pit is central in position and the keel widely bifurcated. The element has an arched profile in lateral view.

Comparison: The platform margins of Ancyrogondolella quadrata are parallel. Ancyrogondolella triangularis has denticles all over the platform margins. Ancyrogondolella aff. rigoi differs in having few low denticles also on the lateral and posterior margins. The denticle pair of the posterior margin characterizing $A$. goldingi n. sp. is missing in $A$. rigoi.

Remarks: A lot of different Lacian forms with a subtriangular outline have been assigned to $A$. rigoi lately. A revision of this concept has to be done in order to clarify the ranges of Lacian taxa, but this is beyond the scope of the present study.

Occurrence: Present in the Lacian and Alaunian of the Dovško Section. Known from the Lacian of Greece (Noyan and Kozur, 2007), the higher Tuvalian 3 to Alaunian of Hungary (e.g., Karádi et al., 2016, 2013) and Italy (e.g., Mazza et al., 2012). (2007)

Ancyrogondolella aff. rigoi (Kozur) in Noyan and Kozur

Fig. 6/1

Material: 4 specimens in 2 samples

Description: This conodont has sub-triangular platform that is the widest at the posterior half and narrower at the anterior half. The anterior platform margins have three to four large denticles that are elongated in direction of the carina. Some ridge-like, low denticles appear on the lateral and posterior margins. The length of the free blade is between $1 / 2$ and $1 / 3$ of the total unit length. The blade is high anteriorly and descends gradually towards the cusp, which is small in size. Behind the cusp one carinal node is present from where secondary carinae start towards the postero-lateral corners. The pit is in a central position, the keel shows a wide bifurcation behind it. In lateral view the element is arched.

Comparison: Ancyrogondolella rigoi has no denticles on the lateral and posterior platform margins. Ancyrogondolella triangularis is more densely ornamented with stout denticles. Ancyrogondolella goldingi n. sp. differs from this species in having two prominent ridge-like denticles in the middle of the posterior margin.

Remarks: The specimen figured here lacks the blade, but it can be studied in other specimens.

Occurrence: Present in the Alaunian 1 of the Dovško Section.

Ancyrogondolella "spatulata" (Hayashi, 1968)

Fig. 6/2

pars 1958 Polygnathus abneptis n. sp., Huckriede, p. 156-157; pl. 14, fig. 14 (only).

non 1968 Gladigondolella abneptis var. spatulata var. nov., Hayashi, p. 69; pl. 2, fig. 5.

1980 Metapolygnathus abneptis spatulatus (Hayashi), Kovács and Kozur, pl. 14, figs. ?3, 4.

non 1980 Epigondolella abneptis spatulata (Hayashi), Krystyn, pl. 13, figs. 12-14.

1991a Epigondolella spatulata (Hayashi), Orchard, p. 312; pl. 2, figs. 4-6, 11.

pars 2001 Ancyrogondolella spatulata (Hayashi), Ishida and Hirsch, p. 236, 238; pl. 3, fig. 7 (only); pl. 4, figs. ?1, ?3, 5.

2009 Epigondolella spatulata Hayashi, Krystyn et al., fig. $4 / 4$.

non 2012 Epigondolella spatulata (Hayashi, 1968), Mazza et al., p. 110; pl. 6, fig. 8.

Material: 10 specimens in 7 samples

Description: This conodont has a sub-triangular platform outline with an expanded posterior part. Two to three large denticles are present on the anterior platform margins, and the rest of the platform margins has several lower denticles. The free blade is between $1 / 2$ and $1 / 3$ unit length. The blade is highest around the platform-blade junction, and it descends gradually towards the anterior and the posterior. The cusp is followed by a larger carinal node. Secondary carinae may start from this node in the direction of the postero-lateral corners, but this feature is not present in every specimen. The pit is centrally located, the keel has a bifurcated termination. In lateral view the lower margin of the element is slightly arched.

Comparison: Ancyrogondolella rigoi has no denticulation on the lateral and posterior margins. The denticles of the platform margins are stouter in A. triangularis and it has a laterally more expanded, triangular platform. The posterior platform of A. uniformis is never as expanded as in A. "spatulata".

Remarks: Ancyrogondolella "spatulata", often assigned to different genera such as Ancyrogondolella, Epigondolella or previously Metapolygnathus, is considered a good biostratigraphic marker of the Lacian 3 (e.g., Krystyn, 2008; Gawlick and Böhm, 2000). Although the original description by Hayashi (1968) includes a spatula-shaped platform as a variety, this conodont differs in many characters from the holotype (Hayashi, 1968, pl. 2, fig. 5), which has a sub- 
circular platform outline, lacks the posterior carina and has a squared keel end. According to the authors, this conodont species is not identical with the species described by Hayashi (1968) and thus it is marked as Ancyrogondolella "spatulata" herein.

Occurrence: Present in the Lacian 3 and the LacianAlaunian transition of the Dovško Section. Known from the Lacian 3 to Alaunian 1 of Austria (e.g., Krystyn et al., 2009; Huckriede, 1958), Japan (e.g., Ishida and Hirsch, 2001) and Timor (Orchard, 1991a).

Ancyrogondolella? transitia (Orchard, 1991a)

Fig. $6 / 3$

1991a Epigondolella transitia n. sp., Orchard, p. 314; pl. 3, figs. 11-13.

2018 Epigondolella transitia Orchard, 1991b, Karádi, p. 164; pl. 1, figs. 1, 7.

2018 Mockina? transitia (Orchard, 1991c), Orchard, p. 177-178.

Material: 1 specimen in 1 sample

Description: This conodont has a posteriorly widened platform that has an asymmetric appearance due to the longer external side and the shorter, but laterally more expanded internal side of the posterior platform. The postero-lateral corners are rounded. The anterior margins have two to three large denticles elongated towards the carina. The rest of the platform is also strongly ornamented with ridge-like, radially oriented denticles. A weak constriction is present between the anterior and posterior parts of the platform. The free blade is approximately $1 / 3$ element length. The blade is high anteriorly and gets lower posteriorly. The cusp is undistinguished in size and it is followed by a posterior carina of one or two nodes. The last node of the carina is large from where an elongated ridge starts in the direction of the less expanded postero-lateral corner. The pit is located just in front of the platform midlength. The broad, asymmetric keel follows the shape of the platform and lacks the bifurcation. The element is slightly arched in lateral view.

Comparison: Ancyrogondolella triangularis and Ancyrogondolella aff. triangularis have bifurcated keel termination. Ancyrogondolella equalis has a symmetric, rectangular platform and a bifid keel. The platform of Ancyrogondolella? praespiculata dovskoensis $\mathrm{n}$. ssp. has a biconvex outline and its keel has two unevenly developed lobes.

Remarks: Orchard (2018) assigned this species to the genus Mockina with a question mark, most probably due to the non-bifid keel in this taxon. In this study, however, it is assigned to the genus Ancyrogondolella with a question mark, because even if the keel termination is not typical for this genus, the rest of the morphological characters stand closer to genus Ancyrogondolella than to genus Mockina. However, the uncertainty on both sides obviously shows, that the issue on classification of the transitional taxa between the Lacian and Alaunian faunas has yet to be solved.

Occurrence: Present in the Alaunian 1 of the Dovško Section. Known from the highest Lacian of British Columbia, Canada (Orchard, 2018, 1991a) and from the Lacian-Alaunian transition of Hungary (Karádi, 2018).
Ancyrogondolella triangularis Budurov, 1972

Fig. 6/4

1972 Ancyrogondolella triangularis n. sp., Budurov, p. 857; pl. 1, figs. 3-6.

1991a Epigondolella triangularis triangularis (Budurov), Orchard, p. 315; pl. 3, figs. 7-9.

2003 Epigondolella triangularis (Budurov), Channell et al., fig. A3/88.

2006 Epigondolella triangularis triangularis (Budurov),

Orchard, pl. 8, figs. 3-5.

pars 2009 Epigondolella triangularis (Budurov and Stefanov), Krystyn et al., fig. 4/2 (only).

2010 Epigondolella triangularis (Budurov, 1972), Balini et al., pl. 4, fig. 7.

pars 2013 Epigondolella triangularis (Budurov, 1972), Karádi et al., pl. 2, fig. 17; pl. 3, figs. 11, 16, 17 (only).

2018 Epigondolella triangularis (Budurov, 1972), Karádi, p. 164-165; pl. 1, figs. 4-8.

2018 Ancyrogondolella triangularis Budurov 1972, Orchard, p. 173; pl. 1, figs. 4-12.

Material: More than 30 specimens in 16 samples

Description: This conodont has a triangular platform that can be asymmetric with one postero-lateral lobe being more developed than the other. Large denticles are present all over the platform margins and they are often elongated in direction of the carina. The free blade is between $1 / 2$ and $1 / 3$ unit length, but closer to $1 / 3$. The blade is high anteriorly and descends gradually towards the cusp. The cusp is undistinguished in size and it is followed by one carinal node from where secondary carinae develop towards the postero-lateral corners. The pit is centrally located and the keel is widely bifurcated behind it. The element has an arched profile in lateral view.

Comparison: Ancyrogondolella aff. triangularis has a strongly asymmetric keel with one lobe being more developed than the other one, and a stepped lower margin in lateral view. Ancyrogondolella? transitia has a more asymmetric platform and a non-bifid keel termination. Ancyrogondolella rigoi has no denticles on the lateral and posterior platform margins.

Occurrence: Present in the Lacian 2 to Alaunian 1 of the Dovško Section. Known from the Lacian 3 of British Columbia, Canada (Orchard, 2018, 1991a), the Lacian 2-3 of the Germany (Budurov, 1972) and Austria (e.g., Krystyn et al., 2009), the Lacian of Italy (Mazza et al., 2012; Balini et al., 2010), the Lacian 2 to the Lacian-Alaunian transition of Hungary (Karádi, 2018; Karádi et al., 2016, 2013).

Ancyrogondolella aff. triangularis Budurov, 1972

Figs. 6/5-6

2006 Epigondolella transitia Orchard, 1991c, Orchard, pl. 8 , fig. 8 .

2018 Ancyrogondolella aff. A. triangularis Budurov, 1972, Orchard, p. 173-174; pl. 1, figs. 13-14.

Material: 2 specimens in 1 sample

Description: This species has an asymmetric platform. The outer side is longer and straight, whereas the platform lobe of the inner side is shorter, but laterally expanded. The platform has strong, often ridge-like denticles all around the margins. The free blade is between $1 / 2$ and $1 / 3$ element length. The 
blade is high anteriorly and descends gradually posteriorly. The cusp is undistinguished in size and it is followed by one larger carinal node. From this node a low ridge may develop in the direction of the outer postero-lateral corner. The pit is slightly forward shifted in front of the platform midlength. The keel shows a short posterior prolongation behind the pit, but the keel end is still bifurcated. The two lobes are unevenly developed, which gives the keel an asymmetric appearance. The longer lobe points to the external postero-lateral corner and the shorter lobe to the internal one. In lateral view the lower margin of the element is gently stepped.

Comparison: The asymmetry, if present, in A. triangularis is never as pronounced as in Ancyrogondolella aff. triangularis, and its lower margin is arched instead of being stepped. The keel termination of Ancyrogondolella? transitia is not bifurcated. Ancyrogondolella? praespiculata dovskoensis $\mathrm{n}$. ssp. has a biconvex platform, a longer posterior carina and a sinuous carinal axis.

Occurrence: Present in the Alaunian 1 of the Dovško Section. Known from the Lacian 3 of British Columbia, Canada (Orchard, 2018).

\section{Ancyrogondolella uniformis (Orchard, 1991a)}

Fig. 6/7

1991a Epigondolella triangularis uniformis n. subsp., Orchard, p. 315; pl. 3, figs. 1-3.

2003 Epigondolella triangularis uniformis Orchard, Channell et al., fig. A3/13.

pars 2003 Epigondolella triangularis (Budurov), Channell et al., figs. A3/17, 38 (only).

2006 Epigondolella triangularis uniformis Orchard, Orchard, pl. 8, fig. 6 .

2012 Epigondolella uniformis (Orchard, 1991b), Mazza et al., p. 110-111; pl. 7, fig. 1 .

pars 2013 Epigondolella uniformis Orchard, 1991, Karádi et al., pl. 3, fig. 9 (only).

pars 2018 Epigondolella uniformis (Orchard, 1991b), Karádi, p. 162, 164; pl. 1, fig. 2 (only).

2018 Ancyrogondolella uniformis (Orchard, 1991c), Orchard, p. 174; pl. 1, figs. 1-3.

Material: More than 10 specimens in 8 samples

Description: The platform of this conodont is subrectangular with only slight expansion of the posterior half. The postero-lateral corners may be rounded. All platform margins bear prominent denticles, which are often elongated towards the carina. The free blade is between $1 / 2$ and $1 / 3$ unit length, but closer to $1 / 3$. The blade is high in the anterior part and gets lower in the direction of the cusp. The cusp is followed by one carinal node. The pit is centrally located and the keel termination is bifurcated. The element has an arched profile in lateral view.

Comparison: Ancyrogondolella triangularis has a triangular platform outline due to the wide expansion of the posterior part. Ancyrogondolella equalis has a longer platform and a longer posterior carina. The platform of Epigondolella ritae n. sp. is obliquely truncated, its posterior carina is longer and the keel termination is squared.

Occurrence: Present in the Lacian 2 to Alaunian 1 of the Dovško Section. Known from the Lacian 3 of British Columbia, Canada (e.g., Orchard, 2018, 1991a), the Lacian 3 and the
Lacian-Alaunian transition of Hungary (e.g., Karádi, 2018; Karádi et al., 2013) and the Lacian and Alaunian of Italy (Mazza et al., 2012).

Genus Epigondolella Mosher, 1968

Type species: Polygnathus abneptis Huckriede, 1958

Description: This genus is characterized by a platform that may be broad or narrow, symmetrical or asymmetrical and generally with dense denticulation on the margins. The length of the free blade usually falls between $1 / 2$ and $1 / 3$ unit length, but closer to $1 / 3$. The posterior carina is composed of at least two carinal nodes. The pit is slightly to moderately shifted anteriorly. The keel is posteriorly prolonged and mostly singlelobed, only in some cases the remnant of a secondary lobe may be present. The keel termination is usually squared or obliquely truncated. The lower margin of the element is stepped or upturned in lateral view.

Comparison: See under genus Ancyrogondolella.

\section{Epigondolella buseri n. sp.}

Figs. 6/8-10

Derivation of name: In honor of Stanko Buser, the Slovenian geologist who also studied this area previously.

Holotype: The specimen in Fig. 6/10 (GeoZS 6084-1)

Type locality: Section along the Dovški Potok Stream at Dovško, near Senovo, eastern Slovenia.

Type stratum: Brownish grey, cherty limestone of Alaunian 1 age.

Material: 5 specimens in 2 samples

Diagnosis: Conodont with sub-parallel platform margins, rounded, ornate posterior end with laterally shifted thorn-like tip projecting posteriorly. High denticles are present on the anterior margins, lower denticles on the rest of the margins. The posterior carina is composed of two nodes. Remnant of a secondary lobe gives the keel an asymmetric termination behind the anterior pit.

Description: This species has a platform with sub-parallel margins, rounded postero-lateral corners and characteristic thorn-like tip on the posterior margin that is not in medial position and projecting posteriorly. The external side of the platform is slightly longer than the internal side. A constriction is present approximately at the middle of the platform. The anterior margins bear two to three denticles on the external side and one to two denticles on internal side. The posterior platform has several lower denticles. The length of the free blade is between $1 / 2$ and $1 / 3$ of the total element length. The blade is anteriorly high and gradually gets lower posteriorly. The cusp is followed by two carinal nodes. The pit is forward shifted and lies below the anterior half of the element. The keel is posteriorly prolonged and has an asymmetric appearance due to the remnant of a secondary lobe. The profile of the unit is stepped in lateral view.

Comparison: Epigondolella spiculata has a more pronounced asymmetry and an angular postero-lateral corner on the external side. The platform of E. kozjanskoensis n. sp. is more symmetric and the denticle fused with the posterior margin is in medial position.

Occurrence: Present in the Alaunian 1 of the Dovško Section. 
Epigondolella kozjanskoensis $\mathrm{n}$. sp.

Figs. 6/11-15

Derivation of name: Named after Kozjansko region of eastern Slovenia.

Holotype: The specimen in Fig. 6/13 (GeoZS 6084-4)

Type locality: Section along the Dovški Potok Stream at Dovško, near Senovo, eastern Slovenia.

Type stratum: Brownish grey, cherty limestone of Alaunian 1 age.

Material: 5 specimens in 1 sample

Diagnosis: Conodont with symmetric platform, subparallel margins and a medially situated posterior tip projecting posteriorly. Stout denticles are present on the anterior margins and lower denticles on the rest of the margins. Two nodes compose the posterior carina. The pit is anterior in postion and the keel end is obliquely truncated.

Description: The platform of this species is symmetric with sub-parallel margins. The postero-lateral corners are rounded or more angular. The anterior platform margins bear two to three large denticles. The posterior platform margins have lower denticles and one obliquely oriented denticle is present in each postero-lateral corner. A marked posteriorly projecting, thorn-like denticle aligned with the carina is fused with the middle part of the posterior platform margin. The free blade is between $1 / 2$ and $1 / 3$ element length. The blade is anteriorly high and descends gradually towards the small cusp. The posterior carina behind the cusp has two separated carinal nodes. The pit is forward shifted in front of the middle of the platform. The keel is wide, posteriorly prolonged and has an obliquely truncated termination. The lower margin of the element stepped in lateral view.

Comparison: The platform of Epigondolella spiculata is asymmetric. The tip of the platform in E. buseri n. sp. is shifted towards one postero-lateral corner. Epigondolella kozjanskoensis n. sp. does not have a remnant of a secondary keel that is characteristic for the other two species.

Occurrence: Present in the Alaunian 1 of the Dovško Section.

Epigondolella ritae $\mathrm{n}$. sp.

Fig. 7/1

pars 2011 Metapolygnathus spatulatus spatulatus, Spatzenegger, table 1, fig. 2 (only).

Derivation of name: Named for Rita, the first author's wife.

Holotype: The specimen in Fig. 7/1 (GeoZS 6085-1)

Type locality: Section along the Dovški Potok Stream at Dovško, near Senovo, eastern Slovenia.

Type stratum: Brownish grey, cherty limestone of Alaunian 1 age.

Material: 1 specimen in 1 sample

Diagnosis: Conodont with a slender, rectangular, slightly asymmetric platform and strong denticulation. The cusp is followed by a posterior carina composed of three denticles. The lower side has a forward shifted pit and a prolonged keel with squared termination.

Description: This conodont has an elongated platform with parallel margins and a rectangular outline. The external side of the platform is longer than the internal side, which gives the element an obliquely truncated and slightly asymmetric appearance. Three sharp denticles are present on both anterior platform margins, but the rest of the platform is also strongly ornamented by several denticles of smaller size. The free blade is long, it is between $1 / 2$ and $1 / 3$ element length. The blade is anteriorly high and descends gradually towards the posterior. The cusp is somewhat smaller than the following three denticles of the posterior carina, which reaches the posterior platform margin. The carinal axis of the element is straight. The forward shifted pit is located just in front of the middle of the platform. The broad keel has a squared posterior end. The lower margin is gently arched in lateral view.

Comparison: The platform of Epigondolella tozeri is symmetric. Ancyrogondolella equalis has a strongly bifurcated keel termination.

Remarks: The same species is figured in the online blog called The Fossil Forum under the title "Ammonites from the Zone of Cyrtopleurites bicrenatus" (Spatzenegger, 2011). Although there is only one specimen of this conodont in the material from the Dovško Section, establishment of a new species is reasonable, because there is a possibility of age calibration with ammonoids based on the figures and faunal lists of the blog. The ammonoid Cyrtopleurites bicrenatus from the Austrian locality and the conodont Norigondolella steinbergensis from the Dovško Section together confirm the lower Alaunian age of Epigondolella ritae n. sp.

Occurrence: Present in the Alaunian 1 of the Dovško Section. Known from the Alaunian 1 of the Hallstatt region, Austria (Spatzenegger, 2011).

Epigondolella senovoensis n. sp.

Figs. 7/2-3

Derivation of name: Named after Senovo, a settlement near the type locality.

Holotype: The specimen in Fig. 7/3 (GeoZS 6084-9)

Type locality: Section along the Dovški Potok Stream at Dovško, near Senovo, eastern Slovenia.

Type stratum: Brownish grey, cherty limestone of the Lacian-Alaunian transition.

Material: 2 specimens in 1 sample

Diagnosis: Conodont with a rectangular, slightly asymmetric platform that has a laterally shifted posterior tip. The anterior margins have few large denticles, small obliquely oriented nodes are present at the postero-lateral corners. Two carinal nodes compose a posterior carina. The pit is anteriorly located and the keel end is asymmetrically forked.

Description: The platform of this species has sub-parallel margins with the external side being longer and the internal side shorter. Two large denticles are present on the external anterior margin and one on the internal anterior margin. One obliquely oriented, low node appears on each postero-lateral corner. The posterior margin has a prominent tip shifted towards the external side of the element due to a projecting low node aligned with the carina. The free blade is between $1 / 2$ and $1 / 3$ unit length. The blade is anteriorly high and descends rapidly, but gradually towards the cusp. The cusp is followed by two larger carinal nodes that are well separated. The pit is lo- 
cated below the anterior half of the element. The keel is posteriorly prolonged and it has an asymmetric forked termination with one lobe being shorter than the other. In lateral view the lower margin of the element is stepped.

Comparison: The platform of Epigondolella slovenica $n$. sp. is sub-triangular in shape. Epigondolella buseri n. sp. and $E$. kozjanskoensis $\mathrm{n}$. sp. have more numerous denticles on the platform and the posterior tip of the platform in E. kozjanskoensis $\mathrm{n}$. sp. is in medial position. None of these species has a forked keel termination.

Occurrence: Present in the upper part of the LacianAlaunian transition and in the Alaunian 1 of the Dovško Section.

\section{Epigondolella slovenica $\mathrm{n}$. sp.}

Figs. 7/4-8

Derivation of name: Named after Slovenia.

Holotype: The specimen in Fig. 7/5 (GeoZS 6074-1)

Type locality: Section along the Dovški Potok Stream at Dovško, near Senovo, eastern Slovenia.

Type stratum: Brownish grey, cherty limestone of Alaunian 1 age.

Material: 8 specimens in 1 sample

Diagnosis: Conodont with a broad, sub-triangular, asymmetric platform. The anterior margins have strong denticulation and the internal postero-lateral corner has one lower node. The posterior carina is composed of two to three separated nodes. The pit is forward shifted, the keel has an asymmetrically pointed termination.

Description: This conodont has a broad platform, which is sub-triangular in shape and somewhat asymmetric with the internal side being shorter than the external side. The posterior margin has a pointed tip, which is never in the carinal axis of the element. The external anterior margin usually bears two to three denticles and the internal anterior margin has usually only one denticle. Denticles on the posterior half of the platform are conical, whereas those on the anterior part are elongated towards the carina. A spike-like denticle is always present at the postero-lateral corner of the internal side. The external side may have a similar character, but it is less pronounced. The free blade is short, it falls between $1 / 3$ and $1 / 4$ unit length. The blade is anteriorly high and descends quite abruptly towards the cusp. The small cusp is followed by two to three well separated nodes of the posterior carina. The pit is forward shifted and it lies distinctly below the anterior half of the element. The keel is broad, posteriorly prolonged and asymmetric with a pointed termination oriented towards the external postero-lateral corner. This conodont has a stepped lower margin in lateral view.

Comparison: Epigondolella spiculata has a narrower platform with a plano-convex outline. The platform margins of E. buseri n. sp. are sub-parallel and it has a longer free blade.

Occurrence: Present in the highest level of the LacianAlaunian transition or the lowest level of the Alaunian 1 in the Dovško Section.

\section{Epigondolella spiculata Orchard, 1991a}

Fig. 7/9

pars 1987 Epigondolella multidentata Mosher, 1970, Mao and Tian, pl. 1, figs. ?16, ?20 (only). 1991a Epigondolella spiculata n. sp., Orchard, p. 312-313; pl. 3, figs. 10, 14, 15.

?2003 Epigondolella spiculata Orchard, Channell et al., figs. A2/38, A2/40.

pars 2003 Epigondolella spiculata Orchard, Ji et al., pl. 1, fig. ?8 (only).

pars 2003 Epigondolella tozeri Orchard, Ji et al., figs. ?13, ?14, ?16 (only).

pars 2018 Mockina spiculata (Orchard, 1991b), Karádi, pl. 2, fig. 8 (only).

2018 Epigondolella spiculata Orchard, 1991c, Orchard, p. 175 ; pl. 3, fig. 16 ; pl. 4, figs. 11-16.

Material: 1 specimen in 1 sample

Description: The platform of this conodont is strongly asymmetric with the external side being longer and straight, the internal side being shorter and more rounded. A constriction occurs in front of the platform midlength, but it is more pronounced on the internal side. Two sharp, backward inclined denticles are present on both anterior margins. The external posterior margin is smooth, only a small elevation of the platform in the postero-lateral corner is visible. The internal posterior margin bears low, node-like denticles. The length of the free blade is approximately $1 / 3$ of the total element length. The blade is anteriorly high and descends gradually, but quite rapidly towards the small cusp. Two larger carinal denticles compose the posterior carina, which continues in a low, elongated denticle fused with the posterior platform margin and projected backwards. The pit is forward shifted and is located below the anterior half of the platform. The keel is wide, posteriorly prolonged, undulating and has a rounded termination. The remnant of a secondary lobe is visible, which gives the keel an asymmetric appearance. The element in lateral view is stepped.

Comparison: The platform of Epigondolella slovenica $\mathrm{n}$. sp. is broader and sub-triangular in shape. Epigondolella buseri $\mathrm{n}$. sp. is similar, but its platform has more rounded poster-lateral corners.

Occurrence: Present in the Alaunian 1 in the Dovško Section. Known from the Alaunian of British Columbia, Canada (Orchard, 2018, 1991a).

Epigondolella tozeri Orchard, 1991a

Figs. 7/10-11

pars 1991a Epigondolella tozeri n. sp., Orchard, p. 313-314; pl. 5, figs. 6-8 (only).

non 2003 Epigondolella tozeri Orchard, Ji et al., pl. 1, figs. 12-16.

2018 Epigondolella tozeri Orchard, 1991c, Orchard, p. 175-176; pl. 4, figs. 10, 17-22.

Material: 2 specimens in 1 sample

Description: This conodont has a slender platform with parallel margins and a quasi-rectangular posterior end. Two to three sharp denticles are present on the anterior platform margins and several lower denticles on the posterior margins. The free blade is short, less than $1 / 3$ unit length. The blade is high anteriorly and lowers posteriorly. The cusp is small and it is followed by a posterior carina composed of two larger denticles. The last carinal denticle is fused with the posterior platform margin, it can even be posteriorly projected. The pit is situated near the middle of the platform. The end of the prolonged keel 
is narrowly rounded or pointed. The elements show a slightly arched profile in lateral view.

Comparison: Ancyrogondolella equalis has a broader platform and a bifurcated keel termination. The platform of Mockina? spinosa is sub-oval instead of rectangular.

Occurrence: Present in the Alaunian 1 of the Dovško Section. Known from the Alaunian of British Columbia, Canada (Orchard, 2018, 1991a).

Genus Metapolygnathus Hayashi, 1968

Type species: Metapolygnathus communisti Hayashi, 1968

Description: This genus has a narrow to moderately broad, generally symmetrical platform. The free blade is of $1 / 2$ element length or longer. The posterior carina is long, composed of at least two carinal nodes. The anterior margins bear low nodes or low denticles. The pit is anteriorly shifted and the keel is posteriorly prolonged with squared or bifurcated termination. The lower margin of the elements is arched in lateral view.

Comparison: See under genus Ancyrogondolella.

Metapolygnathus mazzai Karádi, Kozur and Görög, 2013

Fig. 7/12

2012 Metapolygnathus cf. primitius, Mazza et al., p. 117-118; pl. 8, fig. 12.

pars 2013 Metapolygnathus mazzai Karádi, Kozur and Görög n. sp., Karádi et al., p. 288; pl. 1, figs. 5, 7 (only).

2016 Metapolygnathus mazzai Karádi, Kozur and Görög, 2013, Karádi et al., pl. 1, fig. 6.

Material: 8 specimens in 5 samples

Description: The platform of this conodont is long and rectangular. The anterior margins bear two to four node-like denticles, which are often elongated in the direction of the carina. The rest of the platform is unornamented, only microcrenulation may occur. The free blade is between $1 / 2$ and $1 / 3$ unit length. The blade is high anteriorly and descends gradually towards the cusp. The cusp is undistinguished in size and it is followed by a posterior carina of two nodes, which does not reach the posterior margin. The pit is located slightly in front of the platform midlength. The keel is posteriorly prolonged and its end is bifurcated. This conodont has an arched profile in lateral view.

Comparison: Ancyrogondolella quadrata has a similar, but shorter platform, a shorter posterior carina and a bifid keel without posterior prolongation. The platform margins of Metapolygnathus mersinensis are more upturned, and the nodes on the anterior margins are lower than in Me. mazzai. Additionally, the marginal denticles of Me. mazzai are often elongated, which is not characteristic for Me. mersinensis. Representatives of the genera Epigondolella and Mockina do not have bifurcated keel termination.

Occurrence: Present in the Lacian 1 in the Dovško Section. Known from the higher Tuvalian 3 to Lacian 1 of the Csővár area, Hungary (Karádi et al., 2013), Pizzo Mondello, Italy (Mazza et al., 2012), the Lacian 1 of the Buda Hills, Hungary (Karádi et al., 2016).

Genus Mockina Kozur, 1989b

Type species: Tardogondolella abneptis postera Kozur and Mostler, 1971

Description: This genus is characterized by a biconvex or posteriorly strongly tapering platform and variable denticulation on the margins. The length of the free blade is approximately $1 / 3$ unit length or shorter. The posterior carina consist of minimum two carinal nodes. The pit is anteriorly shifted in front of the middle of the platform. The keel is single-lobed, posteriorly prolonged and has a rounded or pointed termination. The lower margin of the elements in lateral view is stepped, straight or rarely upturned.

Comparison: See under genus Ancyrogondolella.

Mockina medionorica Kozur, 2003

Fig. 7/13

1980 Metapolygnathus multidentatus (Mosher), Kovács and Kozur, pl. 14, fig. 5.

1987 Metapolygnathus posterus (Kozur and Mostler), Vrielynck, p. 157-159; pl. 7, figs. 10-15.

2003 Mockina medionorica n. sp., Kozur, p. 70; pl. 1, figs. 5,6 .

?2018 Mockina medionorica Kozur, 2003, Karádi, p. 167; pl. 3, fig. 3.

Material: 3 specimens in 2 samples

Description: This species has a platform, which is broadest at the anterior part and gently tapers towards the posterior end. Two denticles are present on the external anterior platform margin and one denticle on the internal side. The free blade takes $\sim 1 / 3$ of the total length of the element. The blade is anteriorly high and descends gradually towards the posterior. Two large, separated carinal denticles are developed behind the cusp. The posterior carina ends within the platform. The pit is forwardly shifted below the anterior half of the unit. The keel is posteriorly prolonged and its termination is rounded. This species has a slightly stepped lower margin in lateral view.

Comparison: Mockina aff. medionorica has a shorter posterior carina and an asymmetric keel termination. The platform of Mo. matthewi is broadest in the middle part and it has more denticles on the anterior margins.

Remarks: The second denticle of the posterior carina of the figured specimen is a small one. The specimen figured by Karádi (2018) from the Buda Hills might not belong to this species due to its asymmetrically forked keel end, as there exist very scant data on Mo. medionorica.

Occurrence: Present in the Alaunian 1 in the Dovško Section. Known from the Alaunian of Silicka Brezová, Slovakia (Channell et al., 2003; Kozur, 2003), the Mersin Mélange, Turkey (Moix et al., 2007), the Rudabánya Hills, Hungary (Kovács and Kozur, 1980) and perhaps from the Lacian-Alaunian transition of the Buda Hills, Hungary (Karádi, 2018).

Mockina aff. medionorica Kozur, 2003

Figs. 7/14-15

Material: 2 specimens in 2 samples

Description: The platform of this conodont has subparallel margins and a broadly rounded posterior end. The anterior platform margins bear two conical denticles on both sides. The posterior platform margins are smooth. The anterior trough margin is pronounced, leaving a free blade of $\sim 1 / 3$ unit length. The blade is highest at the platform-blade junction and descends gradually towards both the anterior and the posterior 
ends. The cusp is small and it is followed by one large, well separated carinal denticle. The carina does not reach the posterior platform margin. The pit is located around the middle of the platform. The keel is posteriorly prolonged and it has an asymmetric termination with one lobe being more developed than the other, but this does not create a strong bifurcation. In lateral view the lower margin is slightly arched.

Comparison: Mockina medionorica has a similar platform shape, but it is broadest at the anterior part. Its posterior carina is longer than that of Mockina aff. medionorica. Mockina matthewi as well has a longer posterior carina, more denticles on the anterior platform margin, and a rounded keel termination.

Remarks: The blade shape of Mockina aff. medionorica is quite unusual, not similar to any known representatives of the genera Mockina and Epigondolella. However, the characters of the platform are closest to those of Mo. medionorica, and the accumulation of more data from other localities might reveal whether the two taxa are related or not. It has to be noted that even the two specimens assigned here to Mockina aff. medionorica are slightly different. One of the specimens (Fig. $7 / 15$ ) has one very small accessory denticle in front of the anterior denticles on the external side and low elevations on the posterior platform. This specimen has a nearly straight lower profile. The two specimens may represent different species, but in the light of available data it is not yet clear.

Occurrence: Present in the Lacian 3 and in the lowermost part of the Lacian-Alaunian transitional interval in the Dovško Section.

Mockina aff. postera (Kozur and Mostler, 1971)

Figs. 7/16-18

2018 Mockina aff. postera (Kozur and Mostler, 1971), Karádi, p. 169; pl. 2, fig. 2.

Material: 6 specimens in 2 samples

Description: The platform margins of this species are sub-parallel, the platform tapers slightly from the anterior end towards the posterior. The posterior platform is asymmetric having a pointed tip shifted towards the external side of the element. Two high, conical denticles are present on the external anterior platform margin and one denticle on the internal anterior margin. The rest of the platform is usually unornamented or a backwardly projected denticle may develop on the posterior tip of the platform. The free blade is $\sim 1 / 3$ of the total unit length. The blade is high anteriorly and gradually descends towards the cusp. The small cusp is followed by two carinal denticles, which are aligned towards the tip of the platform. The pit is forward shifted and is located in front of the platform midlength. The keel is posteriorly prolonged following the shape of the platform, and its termination is narrowly rounded. The lower margin of the element is very gently stepped in lateral view.

Comparison: Mockina postera is somewhat smaller, has a shorter free blade and a well pronounced step in the profile of the lower margin. The platform of Mo. medionorica is not asymmetric.

Remarks: This species was documented previously from the Buda Hills in Hungary (Karádi, 2018). The differences between this taxon and Mo. postera are small, but this species seems to be stratigraphically older. The accumulation of more occurrences might reveal whether this species is identical with Mo. postera, and its range should be then extended accordingly.

Occurrence: Present in the Alaunian 1 in the Dovško Section. Known from the Lacian-Alaunian transition of the Buda Hills, Hungary (Karádi, 2018).

Mockina? spinosa Orchard, 2018

Fig. 7/19

pars 1991a Epigondolella tozeri n. sp., Orchard, pl. 5, figs. 1-3 (only).

2001 Mockina aff. spiculata (Orchard, 1991), Ishida and Hirsch, p. 240; pl. 5, fig. 4.

2006 Epigondolella tozeri Orchard, Orchard, pl. 8, fig. 17.

2018 Mockina? spinosa n. sp., Orchard, p. 177; pl. 4, figs. 1-9.

Material: 1 specimen in 1 sample

Description: This species has a sub-oval platform with a narrowly rounded posterior end. Three conical denticles are present on the external anterior margin and two denticles on the internal. The posterior platform margins bear one lower denticle on both sides. The length of the free blade is $\sim 1 / 3$ of the unit length. The anterior part of the blade is moderately high and it descends gradually towards the cusp. The cusp is small and it is followed by a posterior carina composed of two large and well separated denticles. The last denticle of the carina is fused with the posterior platform margin. The slightly forward shifted pit is just in front of the middle of the platform. The keel is narrow, undulating and its termination is narrowly rounded. The element profile in lateral view is almost straight, gently upward bending.

Comparison: Epigondolella tozeri has a more rectangular platform. Mockina matthewi and Mo. medionorica have no denticles on the posterior platform margins, and the latter species has less denticles on the anterior margins. Epigondolella ritae n. sp. has parallel platform margins and an obliquely truncated posterior platform.

Remarks: Mockina? spinosa was originally described from British Columbia (Canada) by Orchard (2018). The specimen of the Dovško Section has a shorter posterior carina and fewer denticles on the lateral margins than the holotype and the other two specimens from Canada.

Occurrence: Present in the Alaunian 1 of the Dovško Section. Known from the higher Lacian 3 to the Alaunian 1 of British Columbia, Canada (Orchard, 2018) and the Alaunian of Japan (Ishida and Hirsch, 2001).

Genus Norigondolella Kozur, 1990

Type species: Paragondolella navicula steinbergensis Mosher, 1968

Description: This genus has an elongated platform that covers nearly the whole element length. The platform margins are without ornamentation, only microcrenulation is present. The carina is highest in the anterior part and descends gradually towards the posterior. The cusp is always the ultimate denticle. The pit is in terminal position and it is surrounded by the broad keel that has rounded or squared posterior end. The species of this genus have a moderately arched profile in lateral view. 

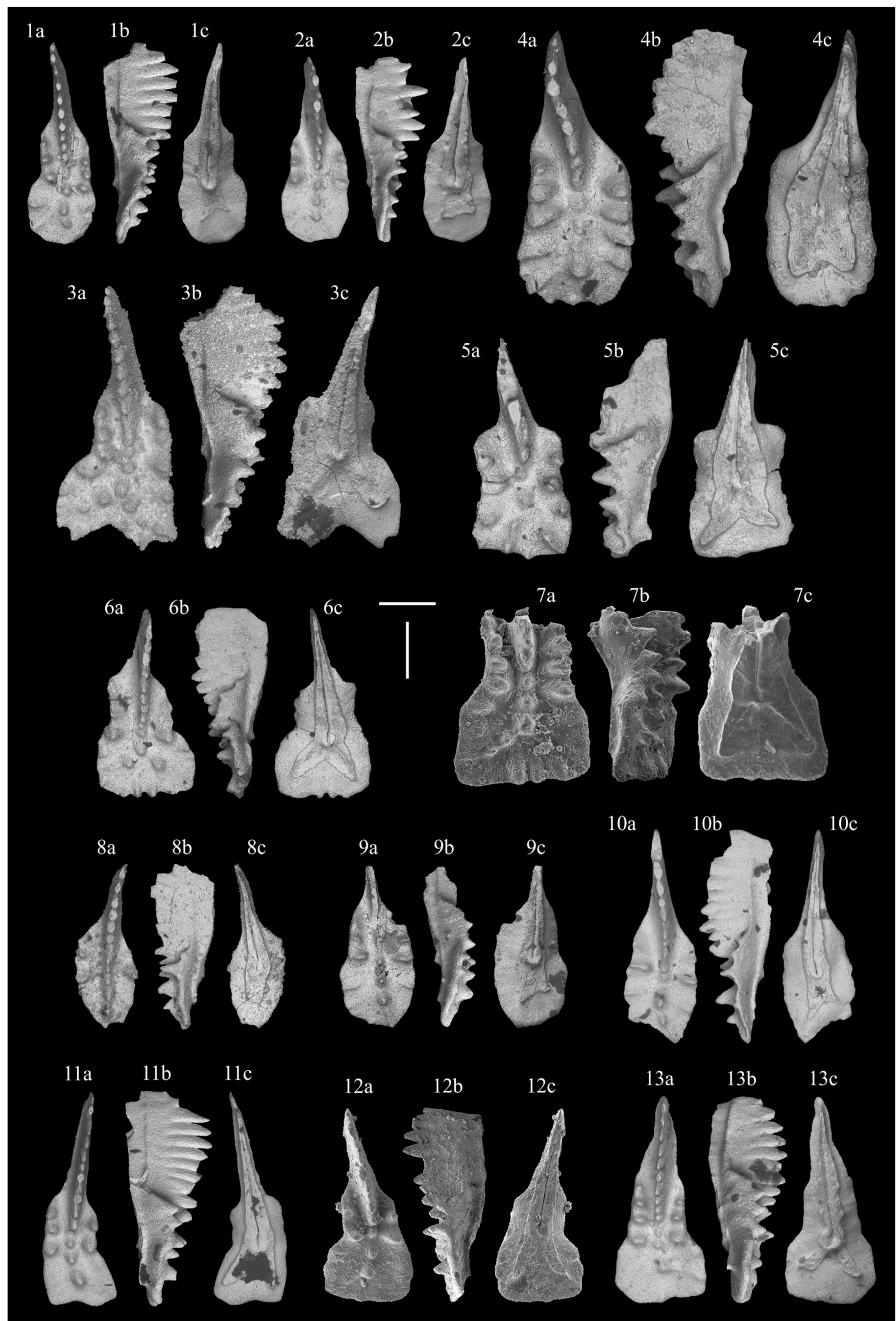

Figure 5. SEM micro-photographs of conodonts of the Dovško succession. Scale bars are $200 \mu \mathrm{m}$ and all specimens are on the same scale. Three views (a. upper; b. lateral; c. lower) are provided of all specimens. 1, 2. Ancyrogondolella? bohorensis n. sp., 1. holotype, sample D16A (GeoZS 6066-1), 2. sample D16A; 3. Ancyrogondolella diakowi posterolobata $\mathrm{n}$. ssp., holotype, sample D20B (GeoZS 6075-1); 4, 5. Ancyrogondolella equalis Orchard (2018), sample D26B; 6, 7. Ancyrogondolella goldingi $\mathrm{n}$. sp., 6. holotype, sample D26B (GeoZS 6088-1), 7. sample $541 \mathrm{~m}$ from the Csővár borehole (Csv-1), Hungary; 8-10. Ancyrogondolella? praespiculata dovskoensis n. ssp., 8. sample D24D, 9. paratype, sample D18A (GeoZS 6070-2), 10. holotype, sample D18A (GeoZS 6070-1); 11. Ancyrogondolella quadrata (Orchard, 1991a), sample D2; 12, 13. Ancyrogondolella rigoi (Kozur) in Noyan and Kozur (2007), 12. sample D5, 13. sample D2. 


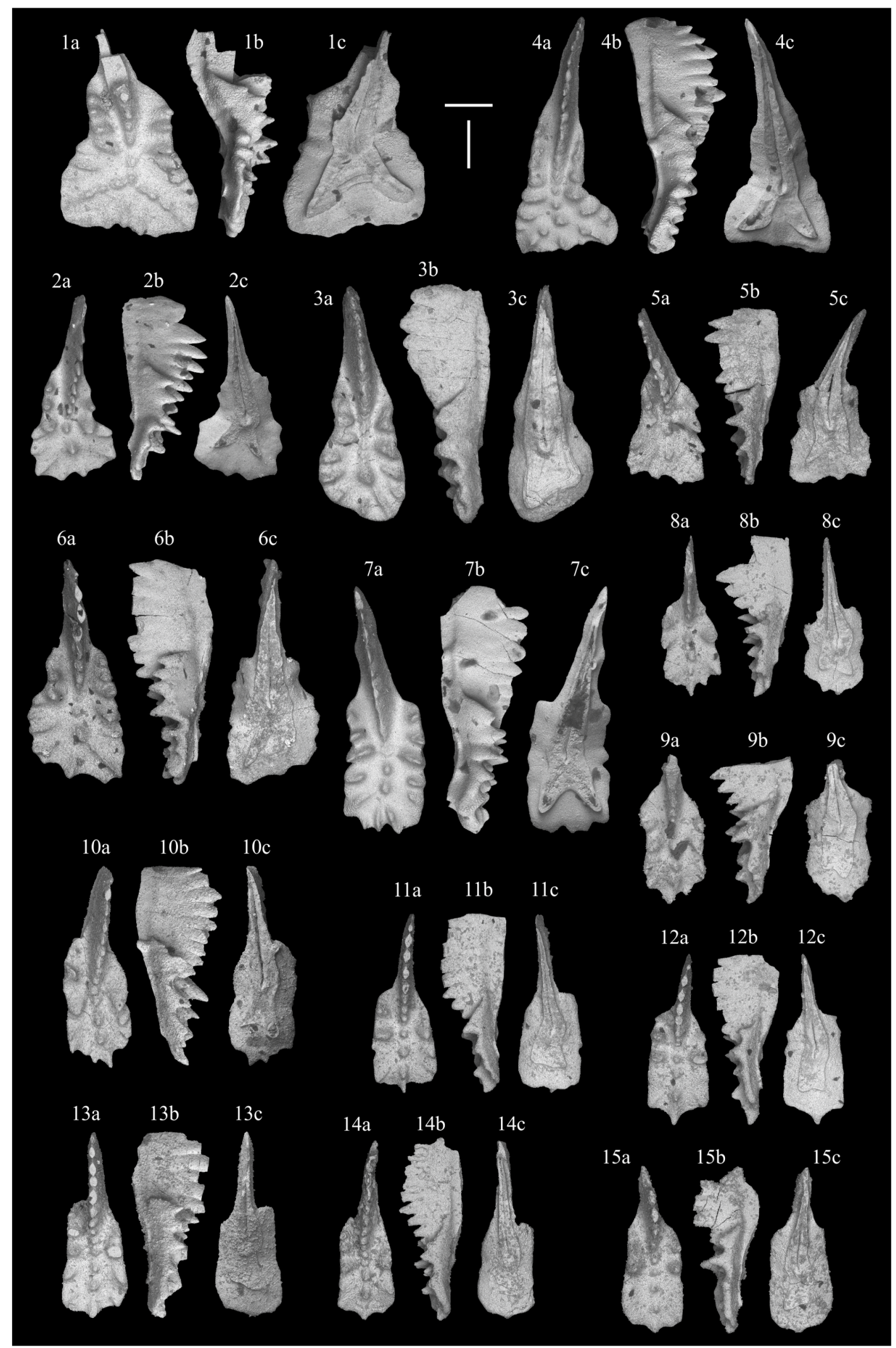

Figure 6. SEM micro-photographs of conodonts of the Dovško succession. Scale bars are $200 \mu \mathrm{m}$ and all specimens are on the same scale. Three views (a. upper; b. lateral; c. lower) are provided of all specimens. 1. Ancyrogondolella aff. rigoi (Kozur) in Noyan and Kozur (2007), sample D25B; 2. Ancyrogondolella "spatulata" (Hayashi, 1968), sample D15A; 3. Ancyrogondolella? transitia (Orchard, 1991a), sample D25B; 4. Ancyrogondolella triangularis Budurov (1972), sample D8; 5, 6. Ancyrogondolella aff. triangularis Budurov (1972), sample D26A; 7. Ancyrogondolella uniformis (Orchard, 1991a), sample D8; 8-10. Epigondolella buseri n. sp., sample D24D, 8. paratype (GeoZS 6084-2), 9. paratype (GeoZS 6084-3), 10. holotype (GeoZS 6084-1); 11-15. Epigondolella kozjanskoensis n. sp., sample D24D, 11. paratype (GeoZS 6084-5), 12. paratype (GeoZS 6084-6), 13. holotype (GeoZS 6084-4), 14. paratype (GeoZS 6084-7), 15. paratype (GeoZS 6084-8). 


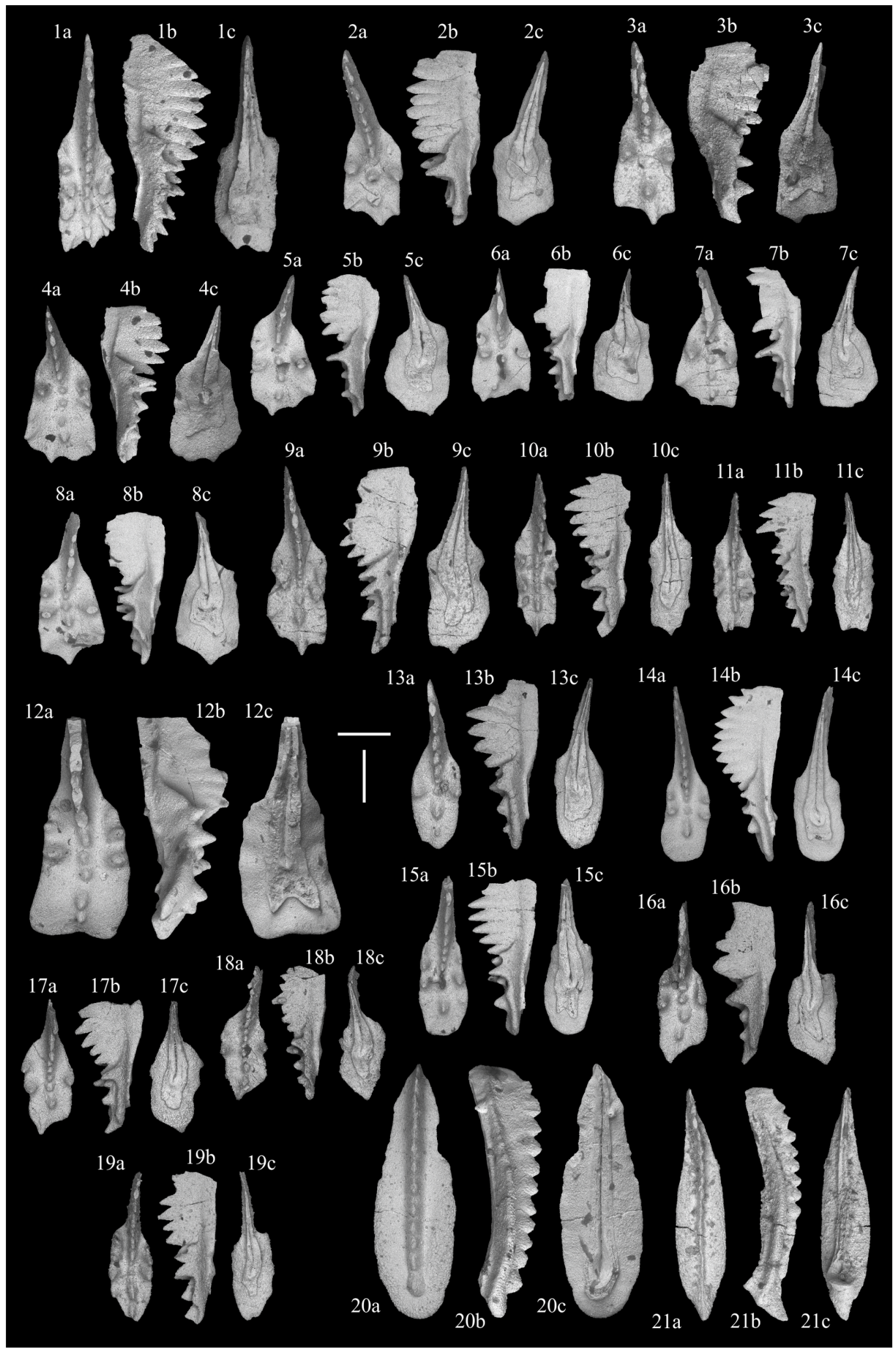

Figure 7. SEM micro-photographs of conodonts of the Dovško succession. Scale bars are $200 \mu \mathrm{m}$ and all specimens are on the same scale. Three views (a. upper; b. lateral; c. lower) are provided of all specimens. 1. Epigondolella ritae n. sp., holotype, sample D25A (GeoZS 6085-1); 2, 3. Epigondolella senovoensis n. sp., 2. paratype, sample D19B (GeoZS 6073-1), 3. holotype, sample D24D (GeoZS 6084-9); 4-8. Epigondolella slovenica n. sp., sample D20A, 4. paratype (GeoZS 6074-2), 5. holotype (GeoZS 6074-1), 6. paratype (GeoZS 6074-3), 7. paratype (GeoZS 6074-4), 8. paratype (GeoZS 6074-5); 9. Epigondolella spiculata Orchard (1991a), sample D24D; 10-11. Epigondolella tozeri Orchard (1991a), sample D24D; 12. Metapolygnathus mazzai Karádi, Kozur and Görög (2013), sample D1; 13. Mockina medionorica Kozur (2003), sample D25B; 14, 15. Mockina aff. medionorica Kozur (2003), 14. sample D18B, 15. sample D16A; 16-18. Mockina aff. postera (Kozur and Mostler, 1971), sample D25B; 19. Mockina? spinosa Orchard (2018), sample D24D; 20. Norigondolella hallstattensis (Mosher, 1968), sample D18A; 21. Norigondolella steinbergensis (Mosher, 1968), sample D25A. 
Norigondolella hallstattensis (Mosher, 1968)

Fig. $7 / 20$

1968 Paragondolella navicula hallstattensis n. subsp., Mosher, p. 939; pl. 117, figs. ?6-9, 10-12.

1980 Gondolella hallstattensis (Mosher), Krystyn, pl. 11, fig. 12.

$1991 \mathrm{~b}$ 'Neogondolella' hallstattensis (Mosher), Orchard, pl. 4 , figs. 5,11 .

2003 Norigondolella hallstattensis (Mosher), Channell et al., figs. A3/21, 29, 87.

2006 Paragondolella? hallstattensis Mosher, Orchard, pl. 8, figs. ?10-12, 13.

2018 Norigondolella hallstattensis (Mosher, 1968), Karádi, p. 170; pl. 3, figs. 7-8.

Material: More than 50 specimens in 3 samples

Description: This conodont species has a short, but broad, leaf-shaped platform. The posterior part of the platform is rounded and it often shows a slight constriction at the level of the cusp. Many specimens have no free blade, in others it is short, composed only of 1-2 denticles. Blade denticles are fused only at their bases, the blade is moderately high in the anterior part and descends gradually towards the posterior end. The cusp is the last denticle and it is somewhat broader than the other denticles of the carina. It is surrounded by the platform. The pit is posteriorly located and deeply excavated. The keel end is rounded. The element has an arched profile.

Comparison: Norigondolella steinbergensis has a slender platform with sub-parallel margins, and a posteriorly projected cusp located at the posteriormost part of the element.

Occurrence: Present in the Lacian 3 and in the lower part of the Lacian-Alaunian transition in the Dovško Section. Known from the Lacian 3 of Austria (e.g., Krystyn, 1980), Slovakia (Channell et al., 2003) and North America (Orchard, 2006, 1991b), the Lacian-Alaunian transition of the Buda Hills, Hungary (Karádi, 2018).

Norigondolella steinbergensis (Mosher, 1968)

Fig. $7 / 21$

1968 Paragondolella navicula steinbergensis n. subsp., Mosher, p. 939; pl. 117, figs. 13-22.

1980 Gondolella steinbergensis (Mosher), Krystyn, pl. 11 , figs. $13-15$.

2003 Norigondolella steinbergensis (Mosher), Channell et al., fig. A2/41; figs. A3/22, 23, 30, 40.

2007 Norigondolella steinbergensis (Mosher), Orchard et al., figs. 7/6-8, 19-22.

2014 Norigondolella steinbergensis, Muttoni et al., figs. $3 / \mathrm{H}, 3 / \mathrm{L}$.

2019 Norigindolella steinbergensis, Kolar-Jurkovšek and Jurkovšek, pl. 43, figs. 14-16.

Material: More than 30 specimens in 4 samples

Description: Long and slender conodont species having sub-parallel platform margins. The very short free blade has 1-2 denticles. The blade is moderately high in the anterior part and gets lower posteriorly. The tips of the blade denticles are often well separated, in some cases they may be fused in the posterior half of the element. The large and sharp cusp is terminally located and it is posteriorly projected. The deeply ex- cavated pit is below the posterior end of the platform. The keel has a broadly rounded termination.

Comparison: Norigondolella hallstattensis has a broader platform that surrounds the cusp.

Occurrence: Present in the Alaunian 1 in the Dovško Section. Known from the Alaunian to Rhaetian of Hungary (Karádi et al., 2016; Pálfy et al., 2007), Austria (e.g., Krystyn, 1980), Slovenia (Kolar-Jurkovšek and Jurkovšek, 2019) and North America (e.g., Orchard et al., 2007), Alaunian and Sevatian of Italy (e.g., Mazza et al., 2012) and Slovakia (Channell et al., 2003), Alaunian of Greece (Muttoni et al., 2014).

\section{ACKNOWLEDGMENTS}

This study was partially supported by the Slovenian Research Agency (No. P1-0011) and partially by the NKFIH PD-131536 Project. Open Access funding enabled and organized by Projekt DEAL. The authors are grateful to Martyn Golding and Ali Murat Kiliç for improving the manuscript with their constructive reviews. Facilities and technical staff of the Geological Survey of Slovenia are gratefully acknowledged, especially Marija Petrović for processing numerous conodont samples and Miloš Miler for his skillful assistance in taking SEM images. The work of Section "SYSTEMATIC PALEONTOLOGY" was conducted by Viktor Karádi and Tea Kolar-Jurkovšek. The final publication is available at Springer via https://doi.org/10.1007/s12583-020-1382-y.

Open Access This article is distributed under the terms of the Creative Commons Attribution 4.0 International License (http://creativecommons.org/licenses/by/4.0/), which permits unrestricted use, distribution, and reproduction in any medium, provided you give appropriate credit to the original author and the source, provide a link to the Creative Commons license, and indicate if changes were made.

\section{REFERENCES CITED}

Balini, M., Bertinelli, A., Di Stefano, P., et al., 2010. The Late CarnianRhaetian Succession at Pizzo Mondello (Sicani Mountains). Albertiana, 39: $36-57$

Budurov, K., 1972. Ancyrogondolella triangularis gen. et sp. n. (Conodonta) Mitteilungen der Gesellschaft der Geologie-und Bergbaustudenten, 21: $853-860$

Buser, S., 1978. Basic Geological Map SFRY, Sheet 33-67, Celje. Federal Geological Survey, Beograd

Buser, S., 1986. Explanatory Book to Basic Geological Map SFRY, Sheet Tolmin and Videm (Udine). Federal Geological Survey, Beograd. 103

Buser, S., 1989. Development of the Dinaric and the Julian Carbonate Platforms and of the Intermediate Slovenian Basin (NW Yugoslavia). Bollettino della Società Geologica Italiana, 40: 313-320

Buser, S., 2009. Geological Map of Slovenia, Scale 1 : 250 000. Geological Survey of Slovenia, Ljubljana

Buser, S., Kolar-Jurkovšek, T., Jurkovšek, B., 2008. The Slovenian Basin during the Triassic in the Light of Conodont Data. Bollettino della Società Geologica Italiana, 127: 257-263

Celarc, B., Kolar-Jurkovšek, T., 2008. The Carnian-Norian Basin-Platform System of the Martuljek Mountain Group (Julian Alps, Slovenia): Progradation of the Dachstein Carbonate Platform. Geologica Carpathica, 59(3): 211-224 
Channell, J. E. T., Kozur, H. W., Sievers, T., et al., 2003. Carnian-Norian Biomagnetostratigraphy at Silická Brezová (Slovakia): Correlation to Other Tethyan Sections and to the Newark Basin. Palaeogeography, Palaeoclimatology, Palaeoecology, 191: 65-109. https://doi.org/10.1016/s0031-0182(02)006545

Cousin, M., 1981. Les Rapports Alpes-Dinarides; Les Confins de l'Italie et de Yougoslavie. Société Géologique du Nord, 5: 1-521

Dunham, R. J., 1962. Classification of Carbonate Rocks according to Depositional Texture. In: Ham, W. E., ed., Classification of Carbonate Rocks, a Symposium. American Association of Petroleum Geology Memoirs, 1: 108-121. https://doi.org/10.1306/m1357

Dzik, J., 1976. Remarks on the Evolution of Ordovician Conodonts. Acta Palaeontologica Polonica, 21:395-455

Embry, A. F., Klovan, J. E., 1971. A Late Devonian Reef Tract on Northeastern Banks Island, N.W.T. Bulletin of Canadian Petroleum Geology, 19: 730-781

Flügel, E., 2004. Microfacies of Carbonate Rocks: Analysis, Interpretation and Application. Springer-Verlag, Berlin Heidelberg. 976

Gale, L., 2010. Microfacies Analysis of the Upper Triassic (Norian) "Bača Dolomite": Early Evolution of the Western Slovenian Basin (Eastern Southern Alps, Western Slovenia). Geologica Carpathica, 61: 293-308

Gale, L., Kolar-Jurkovšek, T., Šmuc, A., et al., 2012. Integrated Rhaetian Foraminiferal and Conodont Biostratigraphy from the Slovenian Basin, Eastern Southern Alps. Swiss Journal of Geosciences, 105: 435-462. https://doi.org/10.1007/s00015-012-0117-1

Gale, L., Celarc, B., Caggiati, M., et al., 2015. Paleogeographic Significance of Upper Triassic Basinal Succession of the Tamar Valley, Northern Julian Alps (Slovenia). Goelogica Carpathica, 66(4): 269-283. https://doi.org/10.1515/geoca-2015-0025

Gale, L., Kolar-Jurkovšek, T., Karničnik, B., et al., 2019. Triassic Deep-Water Sedimentation in the Bled Basin, Eastern Julian Alps, Slovenia. Geologija, 62: 153-173. https://doi.org/10.5474/geologija.2019.007

Gawlick, H.-J., Böhm, F., 2000. Sequence and Isotope Stratigraphy of Late Triassic Distal Periplatform Limestones from the Northern Calcareous Alps (Kälberstein Quarry, Berchtesgaden Hallstatt Zone). International Journal of Earth Sciences, 89: 108-129. https://doi.org/10.1007/s005310050320

Hayashi, S., 1968. The Permian Conodonts in Chert of the Adoyama Formation, Ashio Mountains, Central Japan. Earth Science, 22: 63-77

Huckriede, R., 1958. Die Conodonten der Mediterranen Trias und ihr Stratigraphischer Wert. Paläontologische Zeitschrift, 32(3): 141-175

Ishida, K., Hirsch, F., 2001. Taxonomy and Faunal Affinity of Late CarnianRhaetian Conodonts in the Southern Chichibu Belt, Shikoku, SW Japan. Rivista Italiana di Paleontologia e Stratigrafia, 107(2): 227-250

Jarc, S., Jerina, S., Miler, M., et al., 2017. Mineralogical and Geochemical Characteristics of Mudstones in the Jersovec Chert Deposit. Geologija, 60: 223-234. https://doi.org/10.5474/geologija.2017.016

Ji, Z.-S., Yao, J.-X., Yang, X.-D., et al., 2003. Conodont Zonations of Norian in Lhasa Area, Xizang (Tibet) and Their Global Correlation. Acta Palaeontologica Sinica, 42(3): 382-392 (in Chinese with English Abstract)

Karádi, V., 2018. Middle Norian Conodonts from the Buda Hills, Hungary: An Exceptional Record from the Western Tethys. Journal of Iberian Geology, 44: 155-174. https://doi.org/10.1007/s41513-017-0009-3

Karádi, V., 2021. Evolutionary Trends of the Genus Ancyrogondolella (Conodonta) and Related Taxa in the Norian (Late Triassic). Journal of Earth Science, 32(3): 700-708. https://doi.org/10.1007/s12583-020-1381-z

Karádi, V., Kozur, H. W., Görög, Á., 2013. Stratigraphically Important Lower Norian Conodonts from the Csővár Borehole (Csv-1), Hungary-
Comparison with the Conodont Succession of the Norian GSSP Candidate Pizzo Mondello (Sicily, Italy). In: Tanner, L. H., Spielmann, J. A., Lucas, S. G., eds., The Triassic System. New Mexico Museum of Natural History and Science Bulletin, 61: 284-295

Karádi, V., Pelikán, P., Haas, J., 2016. Conodont Biostratigraphy of Upper Triassic Dolomites of the Buda Hills (Transdanubian Range, Hungary). Bulletin of the Hungarian Geological Society, 146(4): 371-386 (in Hungarian with English Abstract)

Karádi, V., Kolar-Jurkovšek, T., Jurkovšek, B., 2019. The Lower/Middle Norian (Upper Triassic) Transition: Conodonts of the Dovško Succession, Slovenia. 3rd International Congress on Stratigraphy, July 2-5, 2019, Milano, Italy. Abstract Book. Società Geologica Italiana. 53. https://doi.org/10.3301/absgi.2019.04

Karádi, V., Virág, A., Kolar-Jurkovšek, T., et al., 2020. Stress-Related Evolution in Triassic Conodonts and the Middle Norian Juvenile Mortality. In: Guex, J., Torday, J. S., Miller, W. B. Jr., eds., Morphogenesis, Environmental Stress and Reverse Evolution. Springer, Cham, 37-58. https://doi.org/10.1007/978-3-030-47279-5_4

Kolar-Jurkovšek, T., 1982. Conodonts from Amphiclina Beds and Bača Dolomite. Geologija, 25: 167-188

Kolar-Jurkovšek, T., Jurkovšek, B., 2019. Conodonts of Slovenia. Geological Survey of Slovenia, Ljubljana. 259

Kovács, S., Kozur, H., 1980. Stratigraphische Reichweite der Wichtigsten Conodonten (ohne Zahnreihenconodonten) der Mittel-und Obertrias. Geologisch-Paläontologische Mitteilungen Innsbruck, 10(2): 47-78

Kozur, H., 1989a. Significance of Events in Conodont Evolution for the Permian and Triassic Stratigraphy. Courier Forschungsinstitut Senckenberg, 117: 385-408

Kozur, H., 1989b. The Taxonomy of the Gondolellid Conodonts in the Permian and Triassic. Courier Forschungsinstitut Senckenberg, 117: 409-469

Kozur, H., 1990. Norigondolella n. gen., eine neue Obertriassische Conodontengattung. Paläontologische Zeitschrift, 64(1): 125-132

Kozur, H., 2003. Integrated Ammonoid-, Conodont and Radiolarian Zonation of the Triassic. Hallesches Jahrbuch für Geowissenschaften, B25: 49-79

Kozur, H., Mostler, H., 1971. Probleme der Conodontenforschung in der Trias. Geologisch-Paläontologische Mitteilungen Innsbruck, 1(4): 1-19

Krystyn, L., 1980. Triassic Conodont Localities of the Salzkammergut Region (Northern Calcareous Alps). Abhandlungen des Geologischen Bundesanstalt, Second European Conodont Symposium, Guidebook and Abstracts. 61-98

Krystyn, L., 2003. Upper Triassic Substage Boundaries and Their Ammonoid Record: Divided between Gradation, Faunal Turnover and Extinction. Joint Annual Meeting GAC-MAC-SEG, Vancouver

Krystyn, L., 2008. Excursion 1: The Hallstatt Pelagics-Norian and Rhaetian Fossillagerstaetten of Hallstatt. In: Krystyn, L., Mandl, G. W., eds., Upper Triassic Subdivisions, Zonations and Events. Berichte der Geologischen Bundesanstalt, 76: 81-98

Krystyn, L., Mandl, G. W., Schauer, M., 2009. Growth and Termination of the Upper Triassic Platform Margin of the Dachstein Area (Northern Calcareous Alps, Austria). Austrian Journal of Earth Sciences, 102: 23-33

Lindström, M., 1970. A Suprageneric Taxonomy of the Conodonts. Lethaia, 3: $427-445$

Mao, L., Tian, C., 1987. Late Triassic Conodonts from the Uppermost Mailonggang Formation in Mailonggang Village of Lhünzhub County, Xizang (Tibet), China. Bulletin of the Chinese Academy of Geological Sciences, 17: 159-168 (in Chinese with English Abstract)

Mazza, M., Rigo, M., Gullo, M., 2012. Taxonomy and Biostratigraphic 
Record of the Upper Triassic Conodonts of the Pizzo Mondello Section (Western Sicily, Italy), GSSP Candidate for the Base of the Norian. Rivista Italiana di Paleontologia e Stratigrafia, 118(1): 85-130. https://doi.org/10.13130/2039-4942/5993

Moix, P., Kozur, H. W., Stampfli, G. M., et al., 2007. New Paleontological, Biostratigraphic and Paleogeographic Results from the Triassic of the Mersin Mélange, SE Turkey. In: Lucas, S. G., Spielmann J. A., eds., The Global Triassic. New Mexico Museum of Natural History and Science Bulletin, 41: 282-311

Mosher, L. C., 1968. Triassic Conodonts from Western North America and Europe and Their Correlation. Journal of Paleontology, 42(4): 895-946

Muttoni, G., Mazza, M., Mosher, D., et al., 2014. A Middle-Late Triassic (Ladinian-Rhaetian) Carbon and Oxygen Isotope Record from the Tethyan Ocean. Palaeogeography, Palaeoclimatology, Palaeoecology, 399: 246-259. https://doi.org/10.1016/j.palaeo.2014.01.018

Noyan, Ö., Kozur, H., 2007. Revision of the Late Carnian-Early Norian Conodonts from the Stefanion Section (Argolis, Greece) and Their Paleobiogeographic Implications. Neues Jahrbuch für Geologie und Paläontologie Abhandlungen, 245(2): 159-178. https://doi.org/10.1127/0077-7749/2007/0245-0159

Ogorelec, B., Dozet, S., 1997. Upper Triassic, Jurassic and Lower Cretaceous Beds in Eastern Sava Folds-Section Laze at Boštanj (Slovenia). Mining and Metallurgy Quarterly, 44: 223-235

Orchard, M. J., 1991a. Upper Triassic Conodont Biochronology and New Index Species from the Canadian Cordillera. In: Orchard, M. J., McCracken A. D., eds., Ordovician to Triassic Conodont Paleontology of the Canadian Cordillera. Geological Survey of Canada Bulletin, 417: 299-335

Orchard, M. J., 1991b. Late Triassic Conodont Biochronology and Biostratigraphy of the Kunga Group, Queen Charlotte Islands, British Columbia. In: Woodsworth, G. W., ed., Evolution and Hydrocarbon Potential of the Queen Charlotte Basin, British Columbia. Geological Survey of Canada, Paper 90-10: 173-193

Orchard, M. J., 2006. Late Paleozoic and Triassic Conodont Faunas of Yukon and Northern British Columbia and Implications for the Evolution of the Yukon-Tanana Terrane. In: Colpron, M., Nelson, J. L., eds., Paleozoic Evolution and Metallogeny of Pericratonic Terranes at the Ancient Pacific Margin of North America, Canadian and Alaskan Cordillera. Geological Association of Canada Special Paper, 45: 229-260

Orchard, M. J., 2014. Conodonts from the Carnian-Norian Boundary (Upper Triassic) of Black Bear Ridge. New Mexico Museum of Natural History and Science Bulletin, 64: 1-139

Orchard, M. J., 2018. The Lower-Middle Norian (Upper Triassic) Boundary: New Conodont Taxa and a Refined Biozonation. In: Over, D. J., Henderson, C. M., eds., Conodont Studies Dedicated to the Careers and Contributions of Anita Harris, Glen Merrill, Carl Rexroad, Walter Sweet, and Bruce Wardlaw. Bulletins of American Paleontology, 395/396: 165-193
Orchard, M. J., Whalen, P. A., Carter, E. S., et al., 2007. Latest Triassic Conodonts and Radiolarian-Bearing Successions in Baja California Sur. In: Lucas, S. G., Spielmann, J. A., eds., The Global Triassic. New Mexico Museum of Natural History and Science Bulletin, 41: 355-365

Pálfy, J., Demény, A., Haas, J., et al., 2007. Triassic-Jurassic Boundary Events Inferred from Integrated Stratigraphy of the Csővár Section, Hungary. Palaeogeography, Palaeoclimatology, Palaeoecology, 244: 11-33. https://doi.org/10.1016/j.palaeo.2006.06.021

Placer, L., 1999a. Contribution to the Macrotectonic Subdivision of the Border Region between Southern Alps and External Dinarides. Geologija, 41: 223-255

Placer, L., 1999b. Structural Meaning of the Sava folds. Geologija, 41: 191-221

Poljak, M., 2007. Structural-Tectonic Map of Slovenia in Scale $1: 250000$. Geological Survey of Slovenia, Ljubljana. 52

Rigo, M., Mazza, M., Karádi, V., et al., 2018. New Upper Triassic Conodont Biozonation of the Tethyan Realm. In: Tanner, L. H., ed., The Late Triassic World: Earth in a Time of Transition. Topics in Geobiology, 46: 189-235. https://doi.org/10.1007/978-3-319-68009-5_6

Roniewicz, E., 2011. Early Norian (Triassic) Corals from the Northern Calcareous Alps, Austria, and the Intra-Norian Faunal Turnover. Acta Palaeontologica Polonica, 56(2): 401-428. https://doi.org/10.4202/app.2009.0092

Rožič, B., 2016. Paleogeographic Units. In: Novak, M., Rman, N., eds., Geological Atlas of Slovenia. Geological Survey of Slovenia, Ljubljana. 14-15

Rožič, B., Kolar-Jurkovšek, T., Šmuc, A., 2009. Late Triassic Sedimentary Evolution of Slovenian Basin (Eastern Southern Alps): Description and Correlation of the Slatnik Formation. Facies, 55: 137-155. https://doi.org/10.1007/s10347-008-0164-2

Rožič, B., Gale, L., Kolar-Jurkovšek, T., 2013. Extent of the Upper NorianRhaetian Slatnik Formation in the Tolmin Nappe, eastern Southern Alps. Geologija, 56: 175-186. https://doi.org/10.5474/geologija.2013.011

Spatzenegger, A., 2011. Ammonites from the Zone of Cyrtopleurites Bicrenatus, Nor/Alaunium1 of the Hallstatt limestone. The Fossil Forum. http://www.thefossilforum.com/index.php?/blogs/entry/115-ammonites -from-the-zone-of-cyrtopleurites-bicrenatus/

Trotter, J. A., Williams, I. A., Nicora, A., et al., 2015. Long-Term Cycles of Triassic Climate Change: A New $\delta^{18} \mathrm{O}$ Record from Conodont Apatite. Earth and Planetary Science Letters, 415: 165-174. https://doi.org/10.1016/j.eps1.2015.01.038

Vrabec, M., Fodor, L., 2006. Late Cenozoic Tectonics of Slovenia: Structural Styles at the Northeastern Corner of the Adriatic Microplate. In: Pinter, N., Grenerczy, G., Weber, J., et al., eds., The Adria Microplate: GPS Geodesy, Tectonics and Hazards. NATO Science Series, IV, Earth and Environmental Sciences, 61: 151-168

Vrielynck, B., 1987. Conodontes du Trias Perimediterraneen. Systematique, Stratigraphie. Documents des Laboratoires de Géologie Lyon, 97: 1-301 